Historic, archived document

Do not assume content reflects current scientific knowledge, policies, or practices. 



\section{Forest Statistics for Minnesota's \\ Northern Pine Unit}

Forest

Service

North Central

Forest Experiment

Station

Pat Murray

Resource

Bulletin NC-131

进的

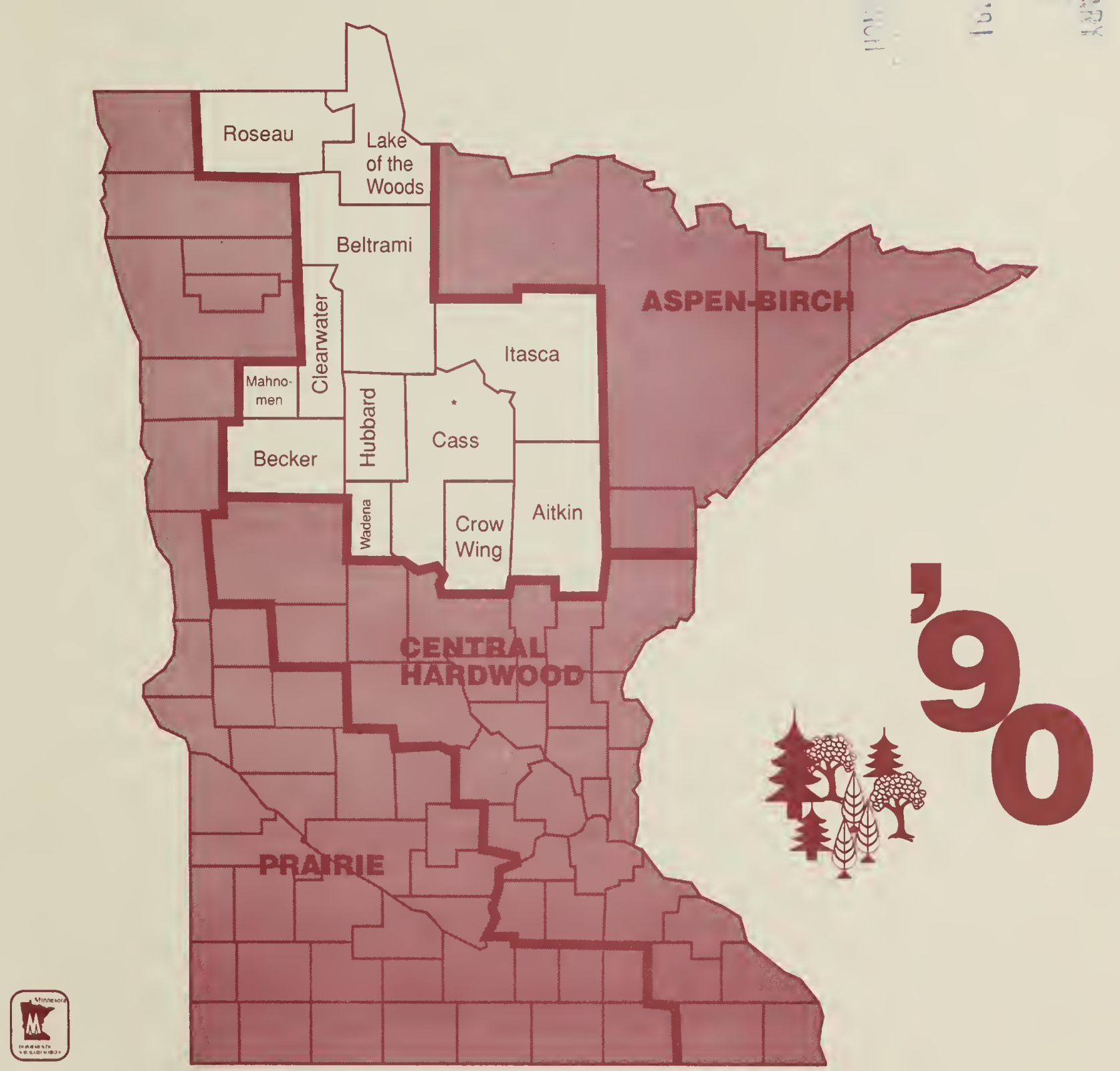


This report includes the most commonly used Forest Inventory and Analysis statistics. However, additional forest resource data can be provided to interested users. Persons requesting additional information that can be provided from the raw inventory data are expected to pay the retrieval costs. These costs range from less than $\$ 100$ for a relatively simple request to $\$ 2,000$ for a complex retrieval involving the services of a Forest Inventory and Analysis computer programmer. Requests will be filled so as to minimize the impact on the Forest Inventory and Analysis Work Unit.

Requests for information may be directed to:

Project Leader

Forest Inventory and Analysis

North Central Forest Experiment Station

1992 Folwell Avenue

St. Paul, Minnesota 55108

Phone: (612) 649-5139

or

State Forester

Minnesota Department of Natural Resources

Forestry Division

P.O. Box 44

500 Lafayette Road

St. Paul, Minnesota 55146

Phone: (612) 296-6491

Area served: Illinois, Indiana, Iowa, Kansas, Michigan, Minnesota, Missouri, Nebraska, North Dakota, South Dakota, Wisconsin

North Central Forest Experiment Station Forest Service-U.S. Department of Agriculture 1992 Folwell Avenue

St. Paul, Minnesota 55108

Manuscript approved for publication May 28, 1991 1991 


\section{FOREWORD}

Forest Inventory and Analysis (FIA) is a continuing endeavor as mandated by the Renewable Forest and Rangeland Resources Planning Act of 1974. Prior inventorles were mandated by the McSweeney-McNary Forest Research Act of 1928. The objective of FIA is to periodically inventory the Nation's forest land to determine its extent, condition, volume of timber, growth, and removals. Up-to-date resource information is essential to frame forest policies and programs. USDA Forest Service regional experiment stations are responsible for conducting these inventorles and publishing summary reports for individual States. The North Central Forest Experiment Station is responsible for forest inventory and analysis in Illinois, Indiana, Iowa, Kansas, Michigan, Minnesota, Missouri, Nebraska, North Dakota. South Dakota, and Wiscon$\sin$.

Fieldwork for the Minnesota Northern Pine Unit forest inventory was begun in July 1988 and completed in October 1990. Reports of four previous inventories of Minnesota's timber resource are dated 1936, 1953, 1962, and 1977.

More accurate survey information was obtained during this survey than otherwise would have been feasible because of intensified field sampling. Such sampling was made possible through the cooperation and assistance of the Minnesota Department of Natural Resources (MDNR). Data for the Northern Pine Unit were collected by contract crews hired and supervised by the MDNR. To aid in determining current timber removals, the MDNR also surveyed primary wood-using plants in the State.

Aerial photos used in the Northern Pine Unit forest inventory were purchased by the State from U.S. Geological Survey. This photography was from the National High Altitude Photography program (NHAP). In addition, MDNR provided $35 \mathrm{~mm}$ true color prints at a scale of $1: 15,840$ of all of the 1977 plot locations for disturbance detection. 


\section{Contents}

Page

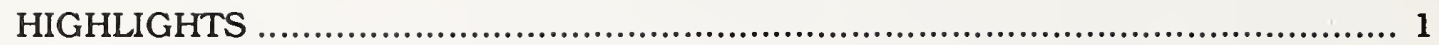

General .................................................................................. 1

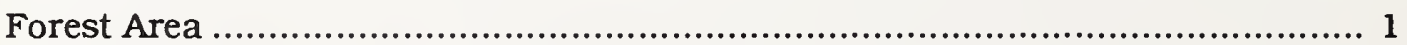

Volume ......................................................................................... 2

Timber Growth, Mortality, and Removals ............................................... 4

APPENDIX ................................................................................ 5

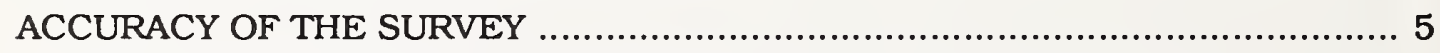

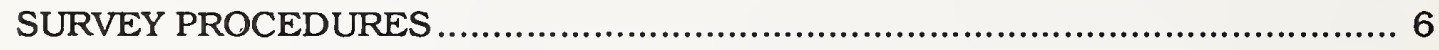

COMPARING MINNESOTA'S FIFTH INVENTORY WITH THE FOURTH

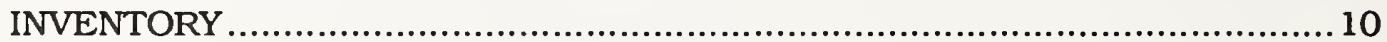

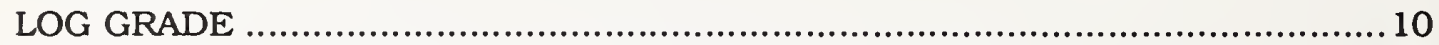

METRIC EQUIVALENTS OF UNITS USED IN THIS REPORT $\ldots \ldots \ldots \ldots \ldots \ldots \ldots \ldots \ldots . . \ldots 16$

TREE SPECIES GROUPS IN MINNESOTA .............................................. 16

DEFINITION OF TERMS ................................................................ 16

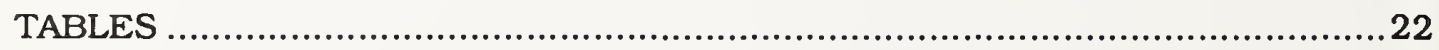




\title{
Forest Statistics for Minnesota's Northern Pine Unit
}

\author{
Pat Murray
}

\section{HIGHLIGHTS}

NOTE: Data from new forest inventories are often compared with data from earlier inventories to determine trends in forest resources. However, for the comparisons to be valid, the procedures used in the two inventories must be similar. As a result of our ongoing efforts to improve the efficlency and reliabllity of the inventory. several changes in procedures and definitions have occurred since 1977. Because some of these changes will make it inappropriate to directly compare the 1990 data with those publtshed for 1977, data from the 1977 inventory have been reprocessed using the 1990 procedures. Please refer to the section labeled "Comparing Minnesota's Fyfth Inventory With the Fourth Inventory" for more detalls. The data in this report are subject to change when inventory data for the entire State have been compiled. It is expected, however, that any such changes will be minor.

\section{General}

The Northern Pine Survey Unit consists of 12 counties in north-central Minnesota (see cover). Two unique geographic features of this Unit include the headwaters of the Mississippi River in Itasca County and the northernmost point of the contiguous United States known as the

Pat Murray, Computer Specialist, began her career with the Forest Service at the Bena Ranger Station of the Chippewa National Forest in 1966. She joined North Central's Forest Inventory and Analysis Unit as a Statistical Assistant in 1976. Pat retired in 1990 after 24 years with the Forest Service.
"Northwest Angle" in Lake of the Woods County. The original vegetation of the Unit was almost exclusively forest except for small areas of native prairle in Hubbard, Becker, and Wadena Counties. This forest included black spruce and tamarack on the peat lands, red pine on the gravelly moraines and till plains, and jack pine on the outwash and along the Mississippi and Crow Wing Rivers. Heavier solls supported balsam fir and white spruce in the northern reaches of the Unit with maple, basswood, and oak in the south. Magnificent white and red pine stands exceeding 30 thousand board feet per acre were not uncommon. Repeated logging, fires, and settlement drastically altered the character of the forest. Today's maturing second- and third-growth forest supports all of the original tree species but in clearly different proportions, with many upland sites supporting the pioneer species of aspen and birch. The lowlands continue to be dominated by black spruce, balsam fir, tamarack, and black ash.

\section{Forest Area}

- The Northern Pine Unit contains 11.1 million acres of land. The area of all forest land in the Unit has declined 2.7 percent since 1977 to 6.3 million acres. The current forest area includes 34 thousand acres of reserved forest land where harvesting is prohibited by statute or administrative designation.

- Ninety-four percent-6 million acres-of the forest land in the Unit is classified as timberland. This is forest land that is capable of or is producing 20 cubic feet or more of industrial wood crops and is not withdrawn from timber harvesting. Between 1977 and 1990, area of timberland in the Unit increased 217,100 acres. 
- Timberland in the Northern Pine Unit has remained relatively stable for the past 30 years (fig. 1). Although the proportion of the aspen type declined slightly over the past three decades, it still comprises nearly 40 percent of the timberland with 2.4 million acres. The areas of black spruce, northern white-cedar, and tamarack timberland have all increased by more than 25 percent since 1977. This increase is attributed to areas classified as unproductive in 1977 and reclassified as marginally productive in 1990 .

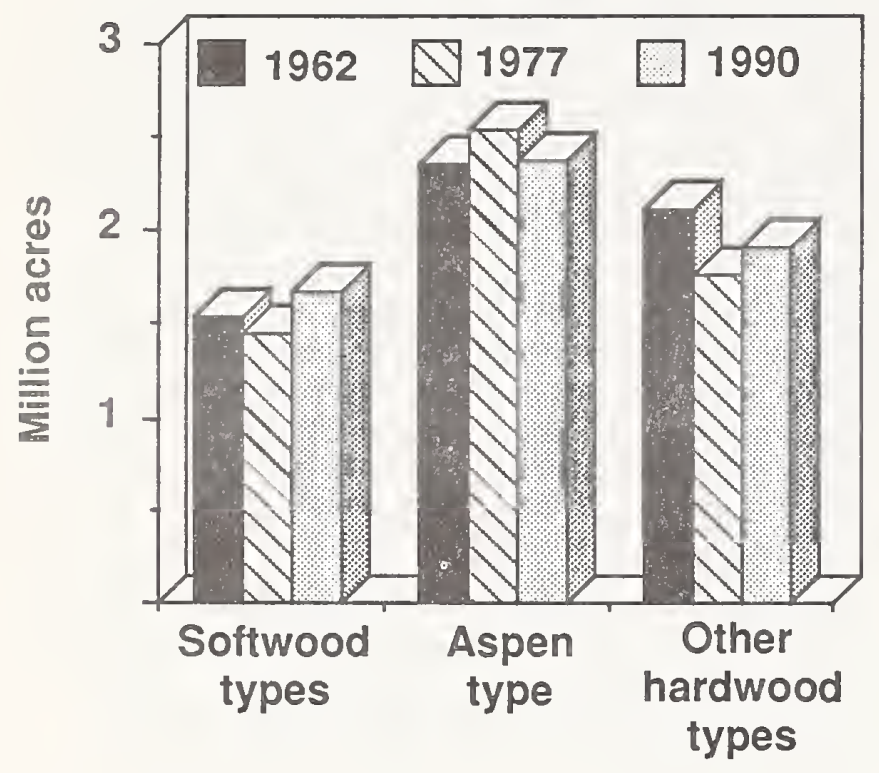

Figure 1.-Area of timberland in the Northern Pine Unit by major forest type group, 1962, 1977, and 1990.

- Fifty-four percent-3.2 million acres-of the Unit's timberland is in public ownership (fig. 2 ). The largest owner is the State of Minnesota, with nearly 1.4 million acres, followed by county and municipal governments with 1.2 million acres, and the Chippewa National Forest with 567 thousand acres. The Northern Pine Unit has 17 percent of all timberland owned by county and municipal governments in the Nation.

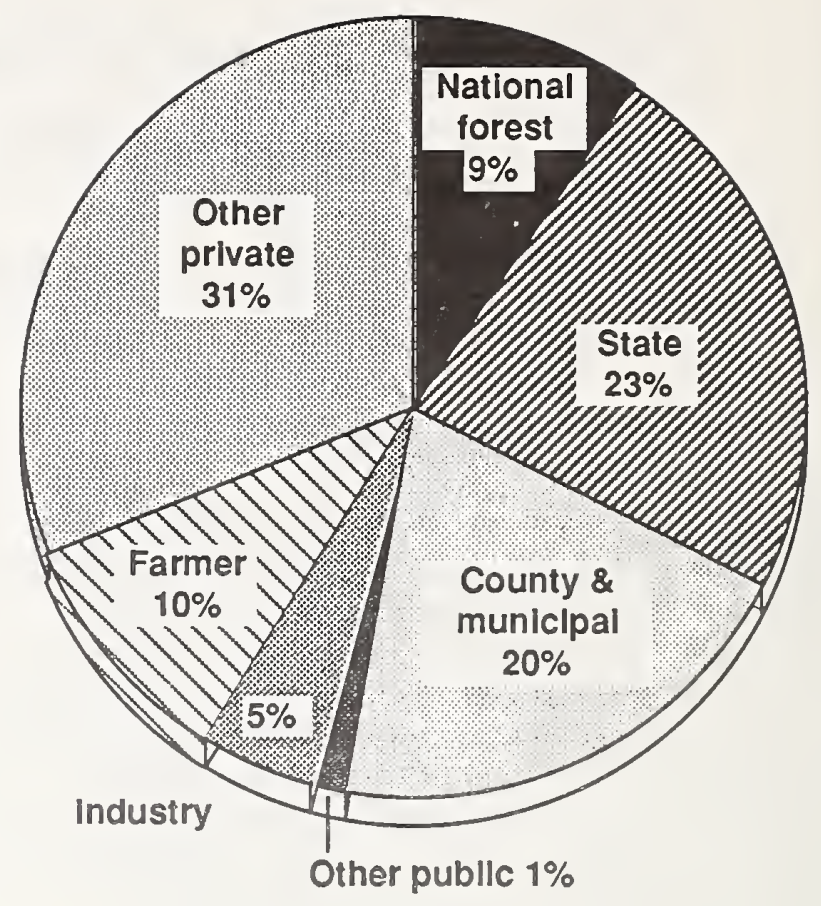

Figure 2.-Distribution of timberland in the Northern Pine Unit by ownership class, 1990.

- Of the 2.7 million acres of timberland that is privately owned, 1.3 million acres are held by miscellaneous individuals. Forest industries own 285 thousand acres. The area of farmer owned timberland stands at 597 thousand acres, down from 1.3 million in 1977.

- The area of sawtimber-size stands has increased by 716 thousand acres since 1977; and the Unit is close to a balanced distribution by stand-size class with 33 percent of timberland in sawtimber, 38 percent in poletimber, and 28 percent in seedlingsapling stands.

\section{Volume}

- The volume of timber in the Northern Pine Unit totals 6.6 billion cubic feet, averaging 1,102 cubic feet per acre, an increase of 31 percent since 1977. 
SOFTWOODS

(1.9 billion cubic feot)

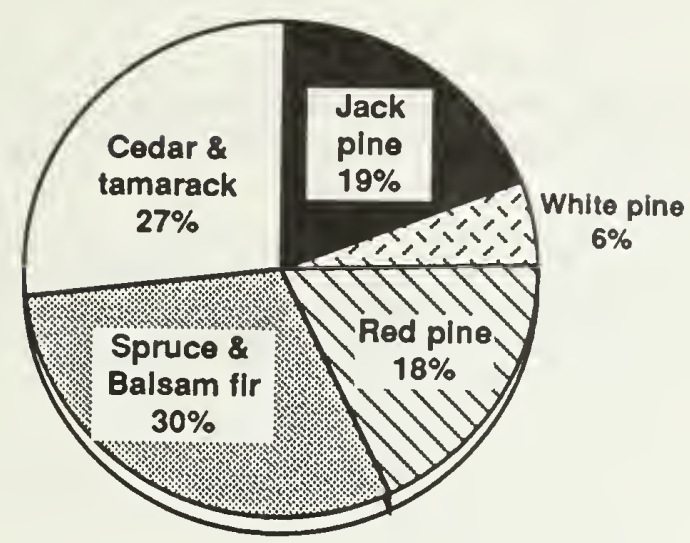

HARDWOODS

(4.6 billion cubic feet)

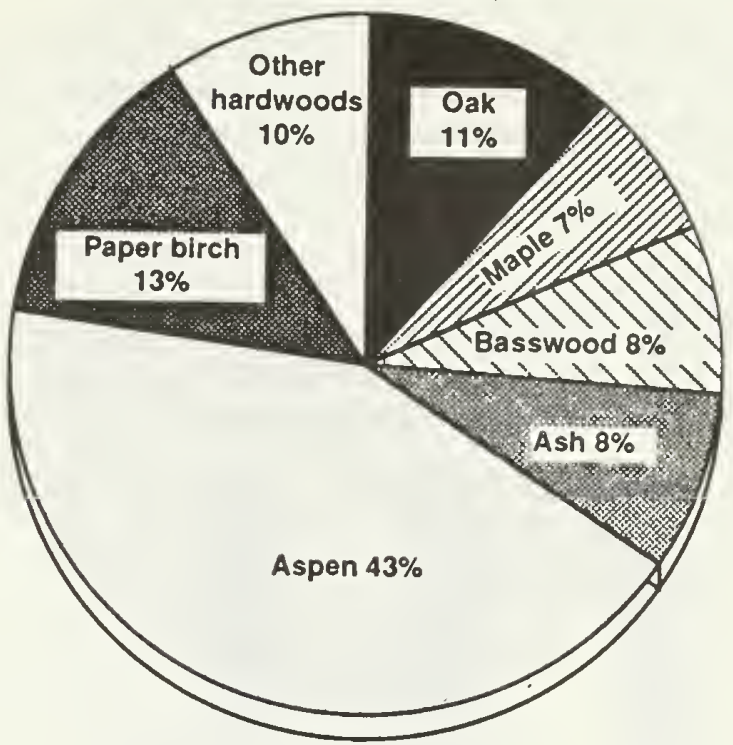

Figure 3.-Volume of growing stock on timberland in the Northern Pine Unit by species group, 1990.

- Aspen accounts for 43 percent of the 4.6 blllion cubic feet of hardwood growing stock in the Unit (fig. 3). Jack, red, and white pine account for 43 percent of the 1.9 blllion cubic feet of softwoods.

- Sawtimber volume in the Northern Pine Unit stands at 15 billion board feet, up 42 percent from 1977. Sawtimber volume averaged 2,512 board feet per acre in 1990 .

- The largest holder of growing-stock volume is county and municipal governments with 1.4 bllion cubic feet, averaging 1,180 cubic feet per acre, of which about 75 percent is hardwoods.

- State lands hold 1.2 billion cubic feet of growing stock, averaging 997 cubic feet per acre. Nearly one-third of the volume on State lands is lowland conifers such as black spruce, tamarack, and northern white-cedar. This is Indicative of the fact that much of the State land is on poor wet sites.

- The Chippewa National Forest contains 743 million cubic feet of growing stock (fig. 4). Volume per acre on the National Forest is 1,310 cubic feet, highest for any ownership class in the Unit.

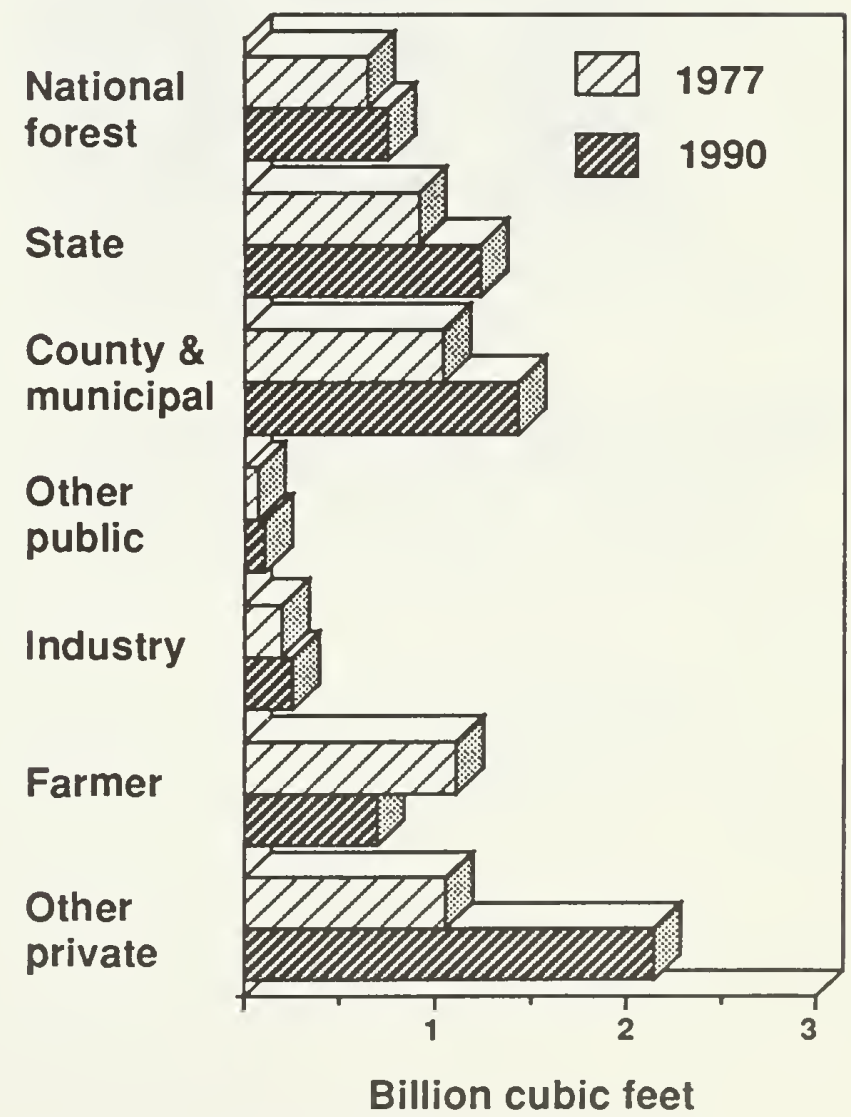

Figure 4.-Net volume of growing stock on timberland in the Northern Pine Unit by ownership class, 1977 and 1990. 


\section{Timber Growth, Mortality, and Removals}

- Net annual growth of growing stock on timberland averaged 169.8 mullion cubic feet per year from 1977 through 1989 (fig. 5). This is an average of 28.4 cubic feet per acre per year.

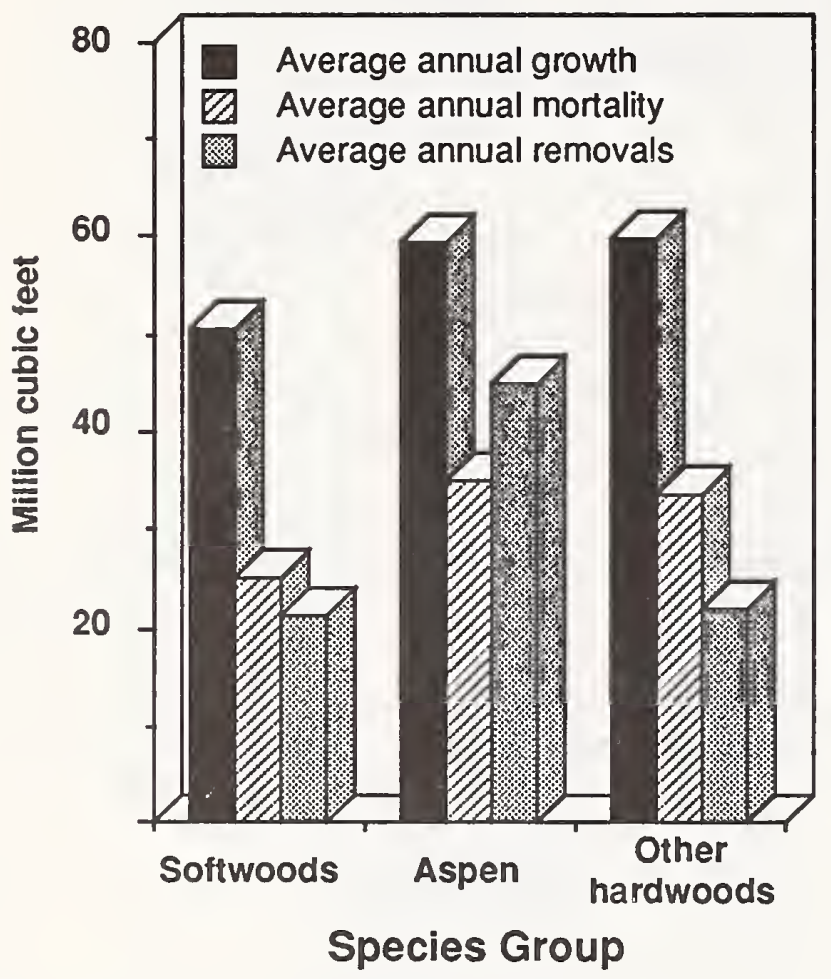

Figure 5.-Average annual growing-stock growth, removals, and mortality on timberland in the Northern Pine Unit by species group, 1977-1989.
- Softwood growth averaged 50.5 million cubic feet, or 2.3 percent of the softwood inventory. Hardwood growth averaged 119.3 million cubic feet, or 2.2 percent of the hardwood inventory.

- Mortality of growing stock averaged 92.3 million cubic feet per year from 1977 through 1989.

- Average annual removals of growing stock from timberland was 87.9 million cubic feet per year from 1977 through 1989. This is 52 percent of average net annual growth.

- Softwood removals for the period averaged 21.2 million cubic feet. Hardwood removals averaged 66.7 million cubic feet.

- Current annual growth of growing stock on timberland was 212.3 million cubic feet in 1989. This is an average of 35.5 cubic feet per acre per year. Current annual growth will usually exceed average annual growth when there is rapid maturation of second-growth forests or in response to increased management on existing stands. Both of these situations are currently occurring throughout the Lake States.

- Aspen growth averaged 59.4 million cubic feet from 1977 through 1989. Removals of aspen averaged 44.8 million cubic feet per year. However, in 1989, aspen growth in the Northern Pine Unit was 66.5 million cubic feet and removals was 76.4 million.

- Total removals of growing stock on timberland in 1988 stood at 117.5 million cubic feet -55 percent of current annual growth. 


\section{APPENDIX}

\section{ACCURACY OF THE SURVEY}

Forest Inventory and Analysis information is based on a sampling procedure designed to provide reliable statistics at the State and Survey Unit levels. Consequently, the reported figures are estimates only. A measure of reliabllity of these figures is given by sampling errors. These sampling errors mean that the chances are two out of three that if a 100 percent inventory had been taken, using the same methods, the results would have been within the limits indicated.

For example, the estimated growing-stock volume in the Unit in $1990,6,586.3$ million cubic feet, has a sampling error of \pm 0.98 percent ( \pm 64.5 million cubic feet). The growing-stock volume from a 100 -percent inventory would be expected to fall between $6,521.8$ and $6,650.8$ million cubic feet $(6,586.3 \pm 64.5$, there being a one in three chance that this is not the case.

The following tabulation shows the sampling errors for the Northern Pine Forest Inventory:

\begin{tabular}{|c|c|c|}
\hline Item & Unit totals & $\begin{array}{l}\text { Sampllng } \\
\text { error }\end{array}$ \\
\hline Growing-stock & (Million cubic feet) & (Percent) \\
\hline Volume (1990) & $6,586.3$ & 0.98 \\
\hline $\begin{array}{c}\text { Average annua } \\
(1977-1989)\end{array}$ & 169.8 & 1.55 \\
\hline $\begin{array}{c}\text { Average annua } \\
(1977-1989)\end{array}$ & ovals & 5.51 \\
\hline Sawtimber & (Million board feet & \\
\hline Volume (1990) & $15,008.8$ & 1.39 \\
\hline $\begin{array}{c}\text { Average annua } \\
\text { (1977-1989) } \\
\text { Average annua }\end{array}$ & $\begin{array}{l}\text { th } \\
\text { ovals }\end{array}$ & 1.74 \\
\hline$(1977-1989)$ & 212.4 & 5.41 \\
\hline $\begin{array}{l}\text { Timberland } \\
\text { Area (1990) }\end{array}$ & $\begin{array}{c}\text { (Thousand acres) } \\
5,975.5\end{array}$ & .49 \\
\hline
\end{tabular}

As survey data are broken down into sections smaller than Survey Unit totals, the sampling error increases. For example, the sampling error for timberland area in a particular county is higher than that for total timberland area in the Unit. This tabulation shows the sampling errors for Unit totals. To estimate sampling error for data smaller than Unit totals, use the following formula:

$$
E=\frac{\text { (SE) } \sqrt{\text { (Unit total area or volume) }}}{\sqrt{\text { (Volume or area smaller than Unit total) }}}
$$

where:

$E$ = sampling error in percent

$\mathrm{SE}=$ Unit total error for area or volume

For example, to compute the error on the area of timberland in the elm-ash-soft maple in the Unit, proceed as follows:

The total area of elm-ash-soft maple type in the Unit from table $3=488,000$ acres

The total area of all timberland in the Unit from table $3=\mathbf{5}, 975,500$

The Unit total error for timberland area from the above tabulation $=0.49$ percent

Using the above formula:

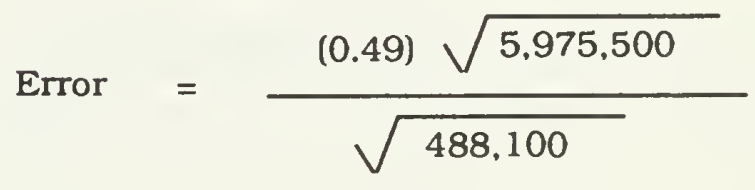

$=\quad \pm 1.71$ percent 


\section{SURVEY PROCEDURES}

The 1990 Minnesota survey used a growth model-enhanced, two-phase sample design. Using this sampling scheme and associated estimators is similar to sampling with partial replacement (SPR), in that a set of randomly located plots is available for remeasurement and a random set of new plots is established and measured. A significant feature of the new Minnesota design is stratification for disturbance on the old sample and use of a growth model to improve regression estimates made on old undisturbed forest plots (fig. 6). Detalled descriptions of the sampling and estimation procedures are presented by Hansen (1990) ${ }^{1}$.

${ }^{1}$ Hansen, Mark H. 1990. A comprehensive sampling system for forest inventory based on an individual tree growth model. St. Paul, MN: University of Minnesota, College of Natural Resources. 256 p. Ph.D. Dissertation.
The growth model used in the Minnesota survey design was the Lake States Stand and Tree Evaluation and Modeling System (STEMS).

These were the major steps in the new survey design:

\section{Aerial photography (Phase 1)}

In this phase two sets of random points were located on current aerial photography. The first is a set of new photo plots and the second is a set of relocated old ground plot locations from the 1977 inventory. Photos were 1:58,000 scale color infrared National High Altitude Photo program (NHAP) prints purchased by the Minnesota

${ }^{2}$ Belcher, David W.; Holdaway, Margaret R.; Brand, Gary J. 1982. A description of STEMS the Stand and Tree Evaluation and Modeling System. Gen. Tech. Rep NC-79. St. Paul, MN: U.S. Department of Agriculture, Forest Service, North Central Forest Experiment Station. 18 p.

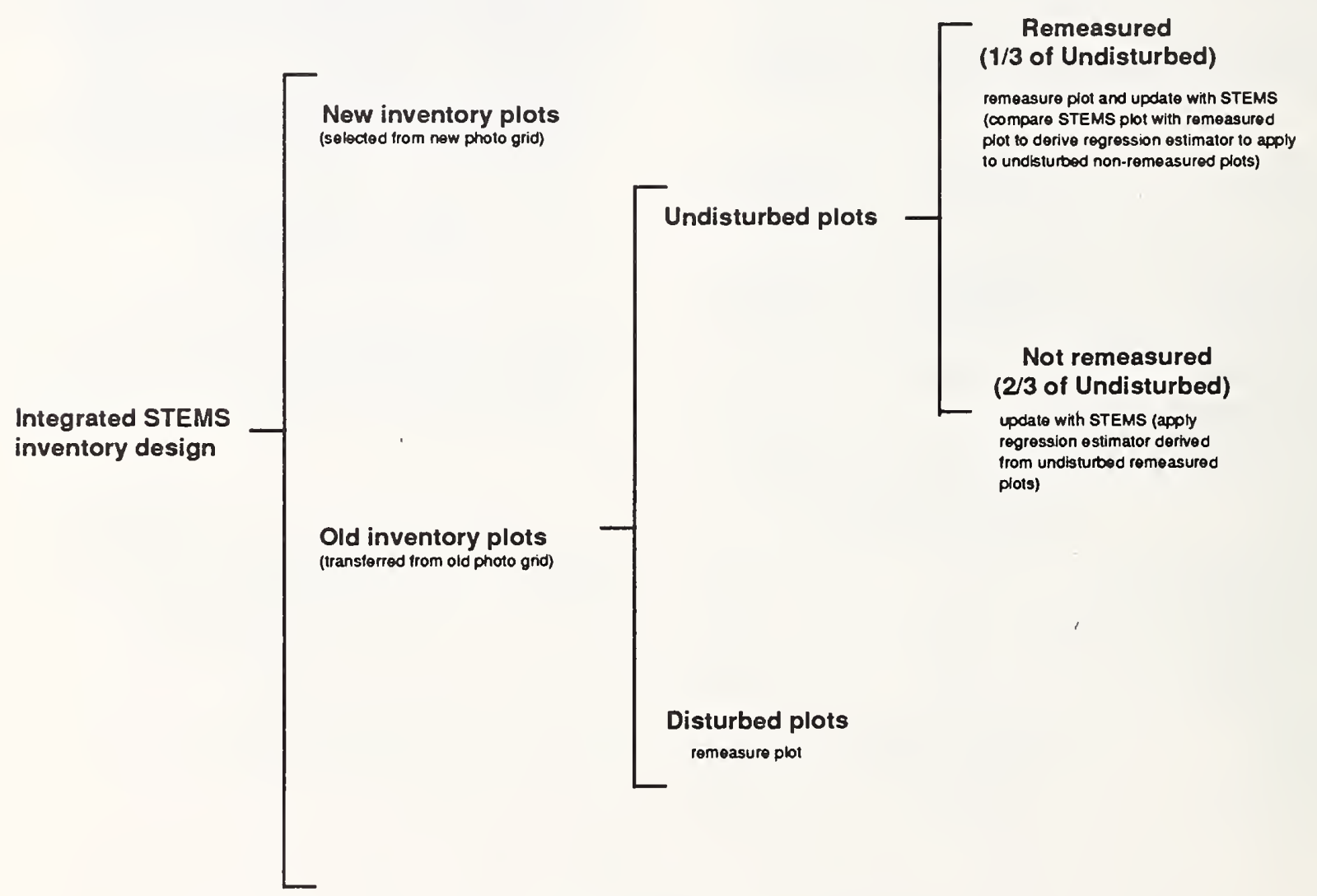

Figure 6.-Overview of the Minnesota sample design. 
Department of Natural Resources (MDNR) from the U.S. Geological Survey. In addition, MDNR provided $35 \mathrm{~mm}$ true color prints at a scale of $1: 15,840$ of all of the 1977 ground plot locations. These $35 \mathrm{~mm}$ prints were used in addition to the NHAP prints to help detect disturbances in the 1977 ground plot locations. The year of photography for each county in the Unit is shown below.

\begin{tabular}{lcc} 
& \multicolumn{2}{c}{ Date } \\
\cline { 2 - 3 } County & NHAP & $35 \mathrm{~mm}$ \\
Aitkin & $1984-1985$ & 1987 \\
Becker & $1983-1984$ & 1988 \\
Beltrami & $1981-1983$ & 1987 \\
Cass & 1981 & 1988 \\
Clearwater & $1982-1983$ & $1987-1988$ \\
Crow Wing & 1981 & 1988 \\
Hubbard & $1984-1985$ & 1988 \\
Itasca & 1981 & $1987-1988$ \\
Lake of the Woods & $1981-1982$ & 1985 \\
Mahnomen & $1983-1984$ & 1988 \\
Roseau & $1982-1983$ & 1988 \\
Wadena & 1983 & 1989
\end{tabular}

The locations of the plots used in the 1977 inventory were transferred to these new photographs. The photographs were then assembled into township mosaics, and a systematic grid of 121 one-acre photo plots (each plot representing approximately 190.4 acres) was overlaid on each township mosalc. Each of these photo plots was examined by aerlal photogrammetrists and classifled stereoscopically based on land use. If trees were present, forest type and stand-stze density class were recorded. All of the 1977 ground plot locations were also examined for disturbance (logging, fire, catastrophic mortality, etc.) with the ald of the $35 \mathrm{~mm}$ photographs. After this examination, all the old "disturbed" sample locations, a one-third sample of the old "undisturbed" sample locations, and a sample of the new photo plots were sent to the field for survey crews to verify the photo classification and to take further measurements. All photo plot locations for the 1990 inventory were examined for the Northern Pine Unit and were classifled as shown in the following tabulation:

\begin{tabular}{lr} 
Photo land class & Photo plots \\
Timberland & 29,729 \\
Reserved forest land & 137 \\
Other forest land & 2,015 \\
Questionable & 645 \\
Nonforest with trees & 1,218 \\
Nonforest without trees & 24,097 \\
Water & 8,112 \\
\hline All classes & 65,953
\end{tabular}

2. Plot measurements (Phase 2)

On plots classiffed as timberland, wooded pasture, or windbreak (at least 120 feet wide), a ground plot was established, remeasured, or modeled. Old plots sent to the field for remeasurement that could not be relocated were replaced with a new plot at the approxdmate location of the old one. Each ground plot consists of a 10-point cluster covering approximately 1 acre. At each point, trees 5.0 inches or more in d.b.h. were sampled on a $37.5 \mathrm{Basal}$ Area Factor (BAF) variable-radius plot, and trees less than 5.0 inches d.b.h. were sampled on a $1 / 300$-acre fixed-radius plot. The measurement procedure for the new and old sample locations was as follows:

\section{a. New inventory plots}

A random sample of the new photo plots was selected for field measurement. Ground plots were established, and measures of current classification such as land use, forest type, and ownership as well as size and condition of all trees on the plot were recorded. These locations were monumented for future remeasurement.

\section{b. Old inventory plots}

These plots were established, monumented, and measured as part of the 1977 field inventory. The procedures for these old plot locations were different from those for the new plots. Old plots were classed as "undisturbed" or "disturbed" in the aerial photo phase of the sampling process. All disturbed plots and a one-third sample of the undisturbed plots were remeasured to obtain estimates of current condition and changes since the last inventory. All trees measured on these plots in 1977 were remeasured or otherwise accounted for, and all new trees were identified and measured. 
All sample plots that were forested at the time of the 1977 inventory and determined to be undisturbed until this inventory were projected to the current time using STEMS. This procedure gives projected estimates of current volume and growth for these undisturbed plots. The comparison of the projected and observed values on the one-third sample of the undisturbed forest plots that were remeasured provided local calibration data to adjust the projected values of the undisturbed plots that were not remeasured. The adjustment procedure is a modified version of the method described by $\mathrm{Smith}^{3}$.

The old sample plots that were not forested in 1977 and were determined to be undisturbed until the current inventory (no evidence of conversion to another land use) were also subsampled (field checked) at the one-third rate. Any changes in land use to forest detected on these plots were used to adjust the two-thirds sample of these plots not field checked. The fleld check of these points in the Northern Pine Unit indicated that no adjustment was necessary.

The undisturbed plots that were not remeasured play a crucial role in the new survey design.

These plots, after careful examination comparing past and current aerial photography. were determined to be undisturbed and had conditions that could be simulated by STEMS.

\footnotetext{
${ }^{3}$ Smith, W. Brad. 1983. Adjusting the STEMS regional growth models to improve local predictions. Res. Note NC-297. St. Paul, MN: U.S. Department of Agriculture, Forest Service, North Central Forest Experiment Station. 5 p.
}

The STEMS growth model was used to "grow" the old plot and tree data to produce an estimate of current data. Thus, these plots were treated as ground plots, even though they were never visited. The plot record for each modeled plot was sent to the field for verification of current ownership information.

All old plots classified as disturbed were sent to the field for remeasurement to assess and verify changes since the last inventory. Disturbance refers to any change on a plot that can be detected on aerial photos and that the STEMS growth processor cannot predict, such as catastrophic mortality, cutting, seedling stands, and land use change.

The estimation procedure for computing statistics from this sampling design was more complicated than the simple two-phase estimation procedure used in the past. In fact, this procedure yielded two independent samples, one coming from the new photo points and the other from the old photo points that are remeasured or modeled. The following tabulation summarizes the distribution of all ground plots for the new inventory design by type of plot:

\section{Ground land use class}

Timberland
Reserved forest land
Other forest land
Nonforest with trees
Nonforest without trees
Water
Total

Old plots remeasured

\begin{tabular}{rr}
2,575 & 1,410 \\
3 & 1 \\
111 & 124 \\
146 & 59 \\
1,189 & 1,776 \\
222 & 386 \\
\hline 4,246 & 3,756
\end{tabular}

\section{Old plots updated}

\begin{tabular}{rr}
$\begin{array}{r}\text { New } \\
\text { plots }\end{array}$ & $\begin{array}{r}\text { Total } \\
\text { plots }\end{array}$ \\
& \\
1,036 & 5,021 \\
16 & 20 \\
61 & 296 \\
47 & 252 \\
661 & 3,626 \\
301 & 909 \\
\hline 2,122 & 10,124
\end{tabular}




\section{Area estimates}

Area estimates were made using two-phase estimation methods. In this type of estimation. a preliminary estimate of area by land use is made from the aerlal photographs (Phase 1) and corrected by the plot measurements (Phase 2). A complete description of this estimation method is presented by Loetsch and Haller $(1964)^{4}$.

Area estimates within the Chippewa National Forest were determined in the same way as other lands but were verifled by comparison with National Forest compartment examination records maintained by the Forest Timber Management Staff. This is an intensive area inventory system in which, over a period of years, each stand in the Forest is mapped on aerial photographs and then classified by ground visits.

\section{Volume estimates}

Estimates of volume per acre were made from the trees measured or modeled on the 10-point plots. Estimates of volume per acre were multiplied by the area estimates to obtain estimates of total volume. Net cubic foot volumes are based on a modification of the method presented by Hahn (1984) ${ }^{5}$ for use in the Lake States. For the Minnesota inventory. the merchantable height equation presented was used in conjunction with Stone's equation to estimate gross volume. This estimate was then corrected by species for varlation in bark and cull volume to yield an estimate of net volume.

The Forest Service reports all board foot volume in International 1/4-inch rule. In Minnesota, the Scribner log rule is commonly used.

${ }^{4}$ Loetsch, F.; Haller, K.E. 1964. Forest inventory, volume I, statistics of forest inventory and information from aerial photographs. BLV Verlagsgesellschaft Munch Basle Vienna. 436 p.

${ }^{5}$ Hahn, Jerold T. 1984. Tree volume and btomass equations for the Lake States. Res. Pap. NC-250. St. Paul, MN: U.S. Department of Agriculture, Forest Service, North Central Forest Experiment Station. 10 p.
Scribner log rule conversion factors were derived from full tree measurements taken throughout the Lake States (Michigan, Wisconsin, and Minnesota) and an equation developed by Wiant and Castenaeda $(1977)^{6}$. The factors (multipliers) used here to convert board foot International volumes to the Scribner rule are shown in the following tabulation:

D.B.H. (inches)

$\frac{\text { Scribner rule conversion factor }}{\text { Softwoods }}$

$9.0-10.9$
$11.0-12.9$
$13.0-14.9$
$15.0-16.9$
$17.0-18.9$
$19.0-20.9$
$21.0-22.9$
$23.0-24.9$
$25.0-26.9$
$27.0-28.9$
$29.0+$

$$
\begin{array}{r}
0.7830 \\
.8287 \\
.8577 \\
.8784 \\
.8945 \\
.9079 \\
.9168 \\
.9240 \\
.9299 \\
.9321 \\
.9357
\end{array}
$$

\section{Growth and mortality estimates}

On remeasured plots, estimates of growth and mortality per acre come from the remeasured diameters of trees and from observation of trees that died between inventories. Growth reported as the average net annual growth between the two inventories (1977 and 1990) is computed from data on remeasurement plots and modeled plots using methods presented by VanDeusen et al. (1986) ${ }^{7}$. Mortality is also average net annual for the remeasurement period. On new plots, where trees were not remeasured, estimates of growth and mortality were obtained by using STEMS to project the growth and mortality of trees for 1 year. Growth and mortality estimates for old undisturbed plots that were updated were derived in the same manner as

\footnotetext{
${ }^{6}$ Wiant, Harry V., Jr.; Castenaeda, Froylan. 1977. Mesavage and Girard's volume tables formulated. BLM4. Denver, CO: U.S. Department of Interior, Bureau of Land Management, Denver Service Center: 1-4.

${ }^{7}$ VanDeusen, P.C.; Dell, T.R.; Thomas, C.E. 1986. Volume growth estimation from permanent horizontal points. Forest Science. 32: 415-422.
} 
remeasured plots. The STEMS growth model was adjusted by Survey Unit to meet local conditions, using data from the undisturbed remeasurement plots. As with volume, total growth and mortality estimates were obtained by multiplying the per acre estimates by area estimates. Current annual growth for 1989 was computed by using the adjusted STEMS model to grow all current inventory plots for 1 year.

\section{Average annual removals estimates}

Average annual growing-stock and sawtimber removals (1977 to 1989 ) were estimated only from the remeasured plots; new plots were not used to estimate removals. These estimates are obtained from trees measured in the last survey and cut or otherwise removed from the timberland base. Because remeasurement plots make up about one-half of the total ground plots, average annual removals estimates have greater sampling errors than volume and growth estimates.

\section{COMPARING MINNESOTA'S FIFTH INVENTORY WITH THE FOURTH INVENTORY}

The following paragraphs highlight some of the procedural changes since the last inventory to assist the reader in analyzing data from this report:

A new volume estimation procedure was developed for the Lake States (see Survey Procedures section), and this procedure was used to compute the 1989 volumes and also to recompute the 1977 volume for growth calculations. Although the adjustment will differ by Survey Unit and species, the recomputed 1977 growing-stock and board foot volumes will generally be greater than those shown in the 1977 report.
Past surveys used only growing-stock trees to determine stand-size class. Current survey procedures require that stand-size class be determined on the basis of all live trees. Therefore, direct comparisons of current inventory data to old inventory data by standsize class may be misleading.

The basic building block for estimating forest area and timber volume has been changed from the Survey Unit to the county. In the past, the statistics were developed at the Unit level and prorated back to the county on the basis of photo-interpretation points. Direct development of county-level data helps users interested in more precise local data, but can make the outcome of comparisons with past estimates uncertain.

\section{LOG GRADE}

In Minnesota the butt log of every sawtimber sample tree was graded for quality on approxdmately one-third of the sample plots. The volume yield by log grade for species in this sample was used to distribute the volume of trees in the ungraded sample into log-grade classes by species group.

Logs were graded on the basis of external characteristics as indicators of quality. Hardwood species were graded according to "A guide to hardwood log grading" $1973^{\circ}$. The best 12 -foot section of the lowest 16-foot hardwood log, or the best 12-foot upper section if the butt log did not meet minimum log-grade standards, was graded as follows:

${ }^{8}$ Rast, Everette D.; Sonderman, David L.; Gammon, Glenn L. 1973. A guide to hardwood log grading. Gen. Tech. Rep: NE-1. Upper Darby, PA: U.S. Department of Agriculture, Forest Service, Northeastern Forest Experiment Station. $31 \mathrm{p}$. 


\section{Forest Service standard grades for hardwood factory saw logs}

\begin{tabular}{|c|c|c|c|c|c|c|c|c|c|}
\hline \multirow{3}{*}{$\begin{array}{l}\text { Grading Factore } \\
\text { Position in tree }\end{array}$} & & & & & \multicolumn{4}{|c|}{ Specifications } & \multirow{3}{*}{$\begin{array}{r}\text { Log grade 3 } \\
\text { Butts \& } \\
\text { uppers }\end{array}$} \\
\hline & & \multicolumn{3}{|c|}{ Log grade 1} & \multicolumn{4}{|c|}{ Log grade 2} & \\
\hline & & $\begin{array}{l}\text { Butts } \\
\text { only }\end{array}$ & & $\begin{array}{c}\text { Butts \& } \\
\text { uppers }\end{array}$ & \multicolumn{4}{|c|}{ Butts \& uppers } & \\
\hline \multicolumn{2}{|c|}{ Scaling diameter, inches } & $13-15^{1}$ & $16-$ & $20+$ & $11 t^{2}$ & & $12+$ & & $8+$ \\
\hline \multicolumn{2}{|c|}{ Length without trim, feet } & \multicolumn{3}{|c|}{$10+$} & $10+$ & $8-9$ & $10-11$ & $12+$ & $8+$ \\
\hline \multirow{2}{*}{$\begin{array}{l}\text { Required } \\
\text { clear cuttings } \\
\text { of each of three } \\
\text { best faces }{ }^{4}\end{array}$} & Min. length, feet & 7 & 5 & 3 & 3 & 3 & 3 & 3 & 2 \\
\hline & Max. number & & 2 & 2 & 2 & 2 & 2 & 3 & No limit \\
\hline
\end{tabular}

Min. proportion

of log length

required in

clear cutting

$5 / 6 \quad 5 / 6 \quad 5 / 6$

$\begin{array}{lll}2 / 3 & 3 / 4 & 2 / 3\end{array}$

$2 / 3$

$1 / 2$

Maximum sweep \& crook allowance
For logs with

less than one-

fourth of end in sound defects
15 percent

30 percent

50 percent

For logs with more than onefourth of end in sound defects

${ }^{1}$ Ash and basswood butts can be 12 inches if they otherwise meet requirements for small \#1's.

2 Ten-inch logs of all species can be \#2 if they otherwise meet requirements for small \#1's.

3 A clear cutting is a portion of a face, extending the width of the face, that is free of defects.

${ }^{4}$ A face is one-fourth of the surface of the $\log$ as divided lengthwise.

${ }^{5}$ Otherwise \#1 logs with 41-60 percent deductions can be \#2.

${ }^{6}$ Otherwise \#2 logs with 51-60 percent deductions can be \#3. 


\section{Forest Service standard specifications for hardwood construction logs (tie and timber logs) ${ }^{1}$}

\begin{tabular}{ll}
\hline Position in tree & Butts and uppers \\
\hline Min. diameter, small end & 8 inches + \\
\hline Min. length without trim & 8 feet \\
\hline Clear cuttings & No requirements \\
\hline Sweep allowance & One-fourth of the diameter at the small end for each \\
& 8 feet of length. \\
\hline
\end{tabular}

Sound surface defects:

Single knots

Any number, if no one knot has an average diameter above the callus in excess of one-third of the log diameter at point of occurrence.

Whorled knots

Any number, if the sum of knot diameters above the callus does not exceed one-third of the log diameter at point of occurrence.

Holes

Any number, provided none has a diameter over onethird of the log diameter at point of occurrence and none extends more than 3 inches into included timber ${ }^{2}$.

Unsound surface defects :

Same requirements as for sound defects if they extend into included timber. No limit if they do not.

${ }^{1}$ These specifications are minimum for the class. If. from a group of logs, factory logs are selected first, thus leaving only nonfactory logs from which to select construction logs, then the quality range of the construction logs so selected is limited, and the class may be considered a grade. If selection for construction logs is given first priority, it may be necessary to subdivide the class into grades.

${ }^{2}$ Included timber is always square, and dimension is judged from small end. 


\section{LOG GRADES FOR EASTERN WHITE PINE}

\begin{tabular}{|c|c|c|c|c|c|c|}
\hline $\begin{array}{l}\text { Log } \\
\text { grade }\end{array}$ & $\begin{array}{l}\text { Minimum } \\
\text { Diameter }\end{array}$ & $\begin{array}{l}\text { size }^{1} \\
\text { Length }\end{array}$ & $\begin{array}{l}\text { Sweep } \\
\text { or crook } \\
\text { allowance }\end{array}$ & $\begin{array}{l}\text { Total cull } \\
\text { allowance } \\
\text { including } \\
\text { sweep }\end{array}$ & $\begin{array}{l}\text { Maximum } \\
\text { weevil } \\
\text { injury }\end{array}$ & $\begin{array}{l}\text { Allowable knot size(inches) } \\
\text { on three best faces or } \\
\text { minimum clearness on } \\
\text { four faces }\end{array}$ \\
\hline & (Inches) & (Feet) & (Percent) & (Percent) & (Number) & (Inches) \\
\hline \multirow[t]{2}{*}{1} & $12 \& 13$ & $8-16$ & 20 & 50 & 0 & Four faces clear full length \\
\hline & $14+$ & $10-16$ & 20 & 50 & 0 & $\begin{array}{l}\text { Two faces clear full length, } \\
\text { or four faces clear } 50 \text { percent } \\
\text { length ( } 6 \text { feet min. length) }\end{array}$ \\
\hline \multirow[t]{2}{*}{2} & $6+$ & $8-16$ & 30 & 50 & 0 & $\begin{array}{l}\text { Sound knots } 1 . e^{4} D / 6 \text { and less } \\
\text { than } 3 \text { inches }{ }^{5}\end{array}$ \\
\hline & & & & & & $\begin{array}{l}\text { Unsound knots: I.e. } 1-1 / 2 \text { inches and } \\
\text { for: butt, logs I.e. D/12 upper } \\
\text { logs I.e.D/10, or four faces } \\
\text { clear } 50 \text { percent of length }\end{array}$ \\
\hline \multirow[t]{2}{*}{3} & $6+$ & $8-16$ & 40 & 50 & $\begin{array}{l}\text { 8-foot logs: } \\
1 \text { weevil }\end{array}$ & $\begin{array}{l}\text { Sound knots l.e.D/3 and } \\
\text { less than } 5 \text { inches }\end{array}$ \\
\hline & & & & & $\begin{array}{l}\text { 10-foot + logs: } \\
2 \text { weevils }\end{array}$ & $\begin{array}{l}\text { Unsound knots I.e. D/6 and } \\
\text { less than } 2-1 / 2 \text { inches }\end{array}$ \\
\hline 4 & $6+$ & $8-16$ & 50 & 50 & No limit & No limit \\
\hline
\end{tabular}

'Plus trim.

${ }^{2}$ Disregard all knots less than $1 / 2$-inch diameter in all grades.

${ }^{3}$ The sum of the diameter of sound knots plus twice the sum of the diameter of unsound knots (in inches) is less than or equal to half of the diameter of the log (inches).

${ }^{4}$ l.e. means less than or equal to.

${ }^{5} \mathrm{D}$ means d.L.b. of log at location of knot. 


\section{LOG GRADES FOR JACK PINE AND RED PINE}

Grade 1: Logs with three or four clear faces. ${ }^{1}$

Grade 2: Logs with one or two clear faces.

Grade 3: Logs with no clear faces.

After the tentative log grade is established from above, the log will be degraded one grade for each of the following, except that no log can be degraded below grade 3. Net scale after deduction for defect must be at least 50 percent of the gross contents of the log.

1. Sweep. Degrade any tentative 1 or 2 log one grade if sweep amounts to 3 or more inches and equals or exceeds one-third of the diameter inside bark at small end.

2. Heart rot. Degrade any tentative 1 or 2 log one grade if conk, massed hyphae, or other evidence of advanced heart rot is found anywhere in it.

${ }^{1} A$ face is one-fourth of the circumference in width extending full length of the log. Clear faces are those free of: knots measuring more than 1/2-inch in diameter, overgrown knots of any size, and holes more than 1/4-inch in diameter. Faces may be rotated to obtain the maximum number of clear ones. 


\section{LOG GRADES FOR ALL OTHER SOFTWOOD LOGS}

Grade 1

1. Logs must be 16 inches in diameter or larger, 10 feet in length or longer, and with deduction for defect not over 30 percent of gross scale.

2. Logs must be at least 75 percent clear on each of three faces.

3. All knots outside clear cutting must be sound and not more than $2-1 / 2$ inches in size.

Grade 2

1. Logs must be 12 inches in diameter or larger, 10 feet in length or longer, and with a net scale after deduction for defect of at least 50 percent of the gross scale deducted for defect.

2. Logs must be at least 50 percent clear on each of three faces or 75 percent clear on two faces.

\section{Grade 3}

1. Logs must be 6 inches in diameter or larger, 8 feet in length or longer, and with a net scale after deduction for defect of at least 50 percent of the gross contents of the log.

Note: A) Diameters are diameter inside bark (d.l.b.) at small end of log.

B) Percent clear refers to percent clear in one continuous section. 


\section{METRIC EGUIVALENTS OF UNITS USED IN THIS REPORT}

1 acre $=4,046.86$ square meters or 0.405

hectare.

1,000 acres $=405$ hectares .

1 cubic foot $=0.0283$ cubic meter .

1 foot $=30.48$ centimeters or 0.3048 meter.

1 inch $=25.4$ millimeters, 2.54 centimeters, or 0.0254 meter.

1 pound $=0.454$ kilograms.

1 ton $=0.907$ metric tons.

\section{TREE SPECIES GROUPS IN MINNESOTA}

\section{SOFTWOODS}

Eastern white pine ........................Pinus strobus Red pine .......................................Pinus resinosa Jack pine .................................Pinus banksiana White spruce ...................................Picea glauca Black spruce .................................Picea mariana Balsam fir .................................Abies balsamea Tamarack Larix laricina Northern white-cedar ............. Thuja occidentalis Other softwoods

Eastern redcedar .............Juniperus virginiana Scotch pine Pinus sylvestris

\section{HARDWOODS}

White oak ${ }^{10}$

White oak Bur oak. Red oak ${ }^{10}$ Quercus alba Quercus macrocarpa

Northern red oak Quercus rubra

Northern pin oak ...........Quercus ellipsoidalis

Black oak Hickory ${ }^{10}$

Shagbark hickory

Bitternut hickory Yellow birch ${ }^{10}$ Quercus velutina Carya ovata Carya cordiformis Betula alleghaniensis

${ }^{9}$ The common and scientific names are based on: Little, Elbert L. 1981. Checklist of native and naturalized trees of the United States. Agric. Handb. 541. Washington, DC: U.S. Department of Agriculture, Forest Service. 385 p.

${ }^{10}$ This species or species group is considered a hard hardwood, with an average specific gravity greater than or equal to 0.50 .

${ }^{11}$ This species or species group is considered a soft hardwood, with an average spectfic gravity of less than 0.50 .
Hard maple ${ }^{10}$

Black maple Acer nigrum Sugar maple Acer saccharum Soft maple ${ }^{11}$

Red maple Acer rubrum

Silver maple Ash ${ }^{10}$

Black ash Fraxinus nigra Green ash Fraxinus pennsylvanica Balsam poplar ${ }^{11}$ Aspen

Bigtooth aspen ${ }^{11}$ Quaking aspen ${ }^{11}$ Populus grandidentata Cottonwood ${ }^{11}$ Basswood ${ }^{11}$ Populus tremuloides Black walnut ${ }^{10}$ Black cherry ${ }^{11}$ Butternut ${ }^{11}$ Elm American $\operatorname{elm}^{11}$....................Ulmus americana Slippery elm $^{11}$..............................Ulmus rubra Rock elm ${ }^{10}$ Ulmus thomasit Paper birch ${ }^{11}$ Hackberry ${ }^{11}$ Black willow ${ }^{11}$ Populus deltoides Tilia americana ..Juglans nigra Prunus serotina Juglans cinerea Other hardwoods

Boxelder ${ }^{11}$ Betula papyrifera Celtis occidentalis Salix nigra Black locust ${ }^{10}$ Red mulberry ${ }^{11}$ Honeylocust ${ }^{10}$ Northern catalpa ${ }^{10}$ Noncommercial species

Eastern hophornbeam Apple Acer negundo American hornbeam Wild plum Hawthorn Robinia pseudoacacia Morus rubra Gleditsia triacanthos Catalpa spectosa Ostrya virgintana .. Malus spp. Carpinus caroliniana ...Prunus spp. Crataegus spp.

\section{DEFINITION OF TERMS}

\section{Average annual removals from growing} stock.-The average net growing-stock volume in growing-stock trees removed annually for forest products (including roundwood products and logging residues) and for other uses (see Other removals). Average annual removals of growing stock are reported for a period of several years (1977 to 1989 in this report) and are based on information obtained from remeasurement plots (see Survey Procedures in Appendix). 
Average annual removals from sawtimber.The average net board foot sawtimber volume of live sawtimber trees removed annually for forest products (including roundwood products and other uses [see Other removals]). Average annual removals of sawtimber are reported for a perlod of several years (1977 to 1989 in this report) and are based on information obtained from remeasurement plots (see Survey Procedures in Appendix).

Commerclal species.-Tree species presently or prospectively suitable for industrial wood products. (Note: Excludes species of typically small size, poor form, or inferlor quality such as hophornbeam, osage-orange, and redbud.)

\section{Commercial forest land.-(See TImberland).}

Cord.--One standard cord is 128 cubic feet of stacked wood, including bark and air space. Cubic feet can be converted to standard cords by dividing by 79 .

\section{County and municipal land.-Land owned by} counties and local public agencies or municipalities, or land leased to these governmental units for 50 years or more.

Cull.-Portions of a tree that are unusable for industrlal wood products because of rot, missing or dead materlal, or other defect.

\section{Current annual growth of growing stock.-}

The annual change in volume of sound wood in live sawtimber and poletimber trees and the total volume of trees entering these classes through ingrowth, less volume losses resulting from natural causes. Current growth is based on an estimate of the current annual increment of each growing stock tree in the inventory.

\section{Current annual growth of sawtimber.-The} annual change in the volume of live sawtimber trees and the total volume of trees reaching sawtimber size, less volume losses resulting from natural causes. Current growth is based on an estimate of the current annual increment of each growing-stock tree in the inventory.
Current annual removals from growing stock. - The current net growing-stock volume in growing-stock trees removed annually for forest products (including roundwood products and logging residues) and for other uses (see Other removals). Current annual removals of growing stock are reported for a single year (1988 in this report) and are based on a survey of primary wood processing mills to determine removals for products and on information from remeasurement plots (see Survey Procedures in Appendix) to determine removals due to land use change.

\section{Current annual removals from sawtimber.-}

The current net board foot sawtimber volume of live sawtimber trees removed annually for forest products (including roundwood products and other uses [see Other removals]). Current annual removals of sawtimber are reported for a single year (1988 in this report) and are based on a survey of primary wood processing mills to determine removals for products and on information from remeasurement plots (see Survey Procedures in Appendix) to determine removals due to land use change.

Diameter class.-A classification of trees based on diameter outside bark, measured at breast height (d.b.h.). Two-inch diameter classes are commonly used in Forest Inventory and Analysis, with the even inch the approximate midpoint for a class. For example, the 6-inch class includes trees 5.0 through 6.9 inches d.b.h.

Dlameter at breast helght (d.b.h.).-The outside bark diameter at 4.5 feet $(1.37 \mathrm{~m})$ above the forest floor on the uphill side of the tree. For determining breast height, the forest floor includes the duff layer that may be present, but does not include unincorporated woody debris that may rise above the ground line.

Farm. Any place from which $\$ 1,000$ or more of agricultural products were produced and sold during the year. 
Farmer-owned land.-Land owned by farm operators whether part of the farmstead or not. (Note: Excludes land leased by farm operators from nonfarm owners, such as railroad companies and States.)

Forest land.-Land at least 16.7 percent stocked by forest trees of any size, or formerly having such tree cover, and not currently developed for nonforest use. (Note: Stocking is measured by comparing specified standards with basal area and/or number of trees, age or size, and spacing.) The minimum area for classification of forest land is 1 acre. Roadside, streamside, and shelterbelt strips of timber must have a crown width of at least 120 feet to qualify as forest land. Unimproved roads and trails, streams, or other bodies of water or clearings in forest areas shall be classed as forest if less than 120 feet wide. (See Tree, Land, Timberland, Reserved forest land, Other forest land, Stocking, and Water.)

Forest industry land.-Land owned by companies or individuals that operate a primary wood-using plant.

Forest type.-A classification of forest land based on the species forming a plurality of live tree stocking. Major forest types in the State are:

Jack pine.-Forests in which jack pine comprises a plurality of the stocking. (Common associates include eastern white pine, red pine, aspen, birch, and maple.)

Red pine.-Forests in which red pine comprises a plurality of the stocking. (Common associates include eastern white pine, jack pine, aspen, birch, and maple.)

White pine.-Forests in which eastern white pine comprises a plurality of the stocking. (Common associates include red pine, jack pine, aspen, birch, and maple.)

Balsam fir.-Forests in which balsam fir and white spruce comprise a plurality of stocking with balsam fir the most common. (Common associates include aspen, maple, birch, northern white-cedar, and tamarack.)

White spruce.-Forests in which white spruce and balsam fir comprise a plurality of the stocking with white spruce the most common. ICommon associates include aspen, maple, birch, northern white-cedar, and tamarack.)

Black spruce.-Forests in which swamp conifers comprise a plurality of the stocking with black spruce the most common.

(Common associates include tamarack and northern white-cedar.)

Northern white-cedar.-Forests in which swamp conifers comprise a plurality of the stocking with northern white-cedar the most common. (Common associates include tamarack and black spruce.)

Tamarack.-Forests in which swamp conifers comprise a plurality of the stocking with tamarack the most common. (Common associates include black spruce and northern white-cedar.)

Oak-hickory.-Forests in which northern red oak, white oak, bur oak, or hickories, singly or in combination, comprise a plurality of the stocking. (Common associates include jack pine, elm, and maple.)

Elm-ash-soft maple.-Forests in which lowland elm, ash, red maple, silver maple, and cottonwood, singly or in combination, comprise a plurality of the stocking.

(Common assoclates include birches, spruce, and balsam fir.)

Maple-basswood-Forests in which sugar maple, basswood, yellow birch, upland American elm, and red maple, singly or in combination, comprise a plurality of the stocking. (Common associates include white pine, elm, and basswood.)

Aspen-Forests in which quaking aspen or bigtooth aspen, singly or in combination. comprise a plurality of the stocking.

(Common associates include balsam poplar, balsam fir, and paper birch.)

Paper birch-Forests' in which paper birch comprises a plurality of the stocking.

(Common assoclates include maple, aspen, and balsam fir.)

Balsam poplar.-Forests in which balsam poplar comprises a plurality of the stocking. (Common assoclates include aspen, elm, and ash.)

Growing-stock tree.-A live tree of commercial species that meets specified standards of size, quality, and merchantability. (Note: Excludes rough, rotten, and dead trees.) 
Growing-stock volume.-Net volume in cubic feet of growing-stock trees 5.0 inches d.b.h. and over, from 1 foot above the ground to a minimum 4.0 inch top diameter outside bark of the central stem or to the point where the central stem breaks into limbs.

Hard hardwoods.-Hardwood species with an average specific gravity greater than 0.50 such as oaks, hard maple, hickories, and ash.

Hardwoods.-Dicotyledonous trees, usually broad-leaved and deciduous. (See Soft hardwoods and Hard hardwoods.)

Indian land.-Land held in trust by the United States for the tribes or individual indians.

Land.-A. Bureau of the Census. Dry land and land temporarlly or partly covered by water such as marshes, swamps, and river flood plains (omitting tidal flats below mean high tide); streams, sloughs, estuaries, and canals less than one-eighth of a statute mile wide: and lakes, reservoirs, and ponds less than 40 acres in area.

B. Forest Inventory and Analysis. The same as the Bureau of the Census, except minimum width of streams, etc., is 120 feet and minimum size of lakes, etc., is 1 acre.

Log grade.-A log classification based on external characteristics as indicators of quality or value. (See Appendix for specific grading factors used.)

Marsh.-Nonforest land that characteristically supports low, generally herbaceous or shrubby vegetation and that is intermittently covered with water.

Merchantable.-Refers to a pulpwood or sawlog section that meets pulpwood or saw-log specifications, respectively.

Miscellaneous Federal land.-Federal land other than National Forest and land administered by the Bureau of Land Management or Bureau of Indian Affairs.

Miscellaneous private land.-Privately owned land other than forest-industry and farmerowned land.
Mortality.-The volume of sound wood in growing-stock and sawtimber trees that die annually.

National Forest land.-Federal land that has been legally designated as National Forest or purchase units, and other land administered by the USDA Forest Service.

Net annual growth of growing stock.- The annual change in volume of sound wood in live sawtimber and poletimber trees and the total volume of trees entering these classes through ingrowth, less volume losses resulting from natural causes.

Net annual growth of sawtimber.-The annual change in the volume of live sawtimber trees and the total volume of trees reaching sawtimber size, less volume losses resulting from natural causes.

Net volume.-Gross volume less deductions for rot, sweep, or other defect affecting use for timber products.

Noncommercial species.-Tree species of typically small size, poor form, or inferior quality that normally do not develop into trees suitable for industrial wood products.

Nonforest land.-Land that has never supported forests, and land formerly forested where use for timber management is precluded by development for other uses. (Note: Includes areas used for crops, improved pasture, residential areas, city parks, improved roads of any width and adjoining clearings, powerline clearings of any width, and 1- to 40-acre areas of water classified by the Bureau of the Census as land. If intermingled in forest areas, unimproved roads and nonforest strips must be more than 120 feet wide and more than 1 acre in area to qualify as nonforest land.)

a. Nonforest land without trees.Nonforest land with no live trees present.

b. Nonforest land with trees.-Nonforest land with one or more trees per acre at least 5 inches d.b.h.

Nonstocked land.-Forest land less than 16.7 percent stocked with all live trees. 
Other forest land.-Forest land not capable of producing 20 cubic feet per acre per year of industrial wood crops under natural conditions and not associated with urban or rural development. These sites often contain tree species that are not currently utilized for industrial wood production or trees of poor form, small size, or inferior quality that are unfit for industrial products. Unproductivity may be the result of adverse site conditions such as sterile soll, dry climate, poor drainage, high elevation, and rockiness. This land is not withdrawn from timber utilization.

Other removals.-Growing-stock trees removed but not utilized for products, or trees left standing but "removed" from the timberland classification by land use change. Examples are removals from cultural operations such as timber stand improvement work, land clearing, and changes in land use.

Poletimber stand.-(Sée Stand-size class.)

Poletimber tree.-A tree of commercial species at least 5.0 inches d.b.h. but smaller than sawtimber stze.

Potential productivity class.-A classification of forest lands in terms of inherent capacity to grow crops of industrial wood. The class identifies the potential growth in merchantable cubic feet/acre/year at culmination of mean annual increment of fully stocked natural stands.

Reserved forest land.-Forest land withdrawn from timber utilization through statute, administrative regulation, designation, or exclusive use for Christmas tree production, as indicated by annual shearing.

Rotten tree.-A tree that does not meet regional merchantability standards because of excessive unsound cull. May include noncommercial tree species.

Rough tree.-A tree that does not meet regional merchantability standards because of excessive sound cull. May include noncommercial tree species.
Salvable dead tree.-A standing or down dead tree considered merchantable by regional standards.

Sapling.-A live tree 1:0 to 5.0 inches d.b.h.

Sapling-seedling stand.-(See Stand-size class.)

Saw log.-A log meeting minimum standards of diameter, length, and defect, including logs at least 8 feet long, sound and straight and with a minimum diameter outside bark (d.o.b.) for softwoods of 7.0 inches 19.0 inches for hardwoods) or other combinations of size and defect specified by regional standards.

Saw-log portion.-That part of the bole of sawtimber trees between the stump and the saw-log top.

Saw-log top.-The point on the bole of sawtimber trees above which a saw log cannot be produced. The minimum saw-log top is 7.0 inches d.o.b. for softwoods and 9.0 inches d.o.b. for hardwoods.

Sawtimber stand.-(See Stand-stze class.)

Sawtimber tree.-A tree of commercial species containing al least a 12 -foot saw log or two noncontiguous saw logs 8 feet or longer, and meeting regional specifications for freedom from defect. Softwoods must be at least 9.0 inches d.b.h. Hardwoods must be at least 11.0 inches d.b.h.

Sawtimber volume.-Net volume of the saw-log portion of live sawtimber in board feet, International 1/4-inch rule (unless specifled otherwise) from stump to a minimum 7 inches top diameter outside bark (d.o.b.) for softwoods and a minimum 9 inches top d.o.b. for hardwoods.

Seedling.-A live tree less than 1.0 inch d.b.h. that is expected to survive. Only softwood seedlings more than 6 inches tall and hardwood seedlings more than 1 foot tall are counted. 
Short-log (rough tree).-Sawtimber-size trees of commercial species that contain at least one merchantable 8- to 11 -foot saw log but not a 12 -foot saw $\log$.

Site index.-An expression of forest site quality based on the height of a free-growing dominant or codominant tree of a representative species in the forest type at age 50 .

Soft hardwoods.-Hardwood species with an average specific gravity less than 0.50 such as gum, yellow-poplar, cottonwood, red maple, basswood, and willow.

Softwoods. - Coniferous trees, usually evergreen, having needles or scale-like leaves.

Stand.-A group of trees on a minimum of 1 acre of forest land that is stocked by forest trees of any size.

Stand-size class.-A classification of stocked (see Stocking) forest land based on the size class of live trees on the area; that is. sawtimber, poletimber, or seedlings and saplings.

a. Sawtmber stands. - Stands with half or more of live stocking in sawtimber or poletimber trees, and with sawtimber stocking at least equal to poletimber stocking.

b. Poletimber stands.-Stands with half or more live stocking in poletimber and/or sawtimber trees, and with poletimber stocking exceeding that of sawtimber.

c. Sapling-seedling stands.-Stands with more than half of the live stocking in saplings and/or seedlings.

State land.-Land owned by States or leased to them for 50 years or more.

Stocking.-The degree of occupancy of land by live trees, measured by basal area and/or the number of trees in a stand by size or age and spacing, compared to the basal area and/or number of trees required to fully utllize the growth potential of the land; that is, the stocking standard.
A stocking percent of 100 indicates full utilization of the site and is equivalent to 80 square feet of basal area per acre in trees 5.0 inches d.b.h. and larger. In a stand of trees less than 5 inches d.b.h., a stocking percent of 100 would indicate that the present number of trees is sufficient to produce 80 square feet of basal area per acre when the trees reach 5 inches d.b.h.

Stands are grouped into the following stocking classes:

Overstocked stands.-Stands in which stocking of live trees is 133 percent or more.

Fully stocked stands.-Stands in which stocking of live trees is from 100.0 to 132.9 percent.

Medium stocked stands.-Stands in which stocking of live trees is from 60.0 to 99.9 percent.

Poorly stocked stands.-Stands in which stocking of live trees is from 16.7 to 59.9 percent.

Nonstocked areas.-Timberland on which stocking of live trees is less than 16.7 percent.

Timberland.-Forest land that is producing or capable of producing in excess of 20 cubic feet per acre per year of industrial wood crops under natural conditions, that is not withdrawn from timber utilization, and that is not associated with urban or rural development. Currently inaccessible and inoperable areas are included.

Tree.-A woody plant usually having one or more perennial stems, a more or less definitely formed crown of foliage. and a height of at least 12 feet at maturity.

Tree size class.-A classification of trees based on diameter at breast height, including sawtimber trees, poletimber trees, saplings. and seedlings.

Upper stem portion.-That part of the bole of sawtimber trees above the saw-log top to a minimum top diameter of 4.0 inches outside bark or to the point where the central stem breaks into limbs. 
Water.-(a) Bureau of the Census.-Permanent inland water surfaces, such as lakes, reservoirs, and ponds at least 40 acres in area; and streams, sloughs, estuaries, and canals at least one-eighth of a statute mile wide.

(b) Noncensus.-Permanent inland water surfaces, such as lakes, reservoirs, and ponds from 1 to 39.9 acres in area; and streams, sloughs, estuaries, and canals from 120 feet to one-eighth of a statute mile wide.

Wooded strip.-An acre or more of natural continuous forest land that would otherwise meet survey standards for timberland except that it is less than 120 feet wide.

\section{TABLES}

Table 1.-Area of land by county and major land-use class, Northern Pine Unit, Minnesota, 1990

Table 2.-Area of timberland by county and ownership class, Northern Pine Unit, Minnesota, 1990

Table 3.-Area of timberland by county and forest type, Northern Pine Unit, Minnesota, 1990

Table 4.-Area of timberland by county and stand-size class, Northern Pine Unit, Minnesota, 1990

Table 5.-Area of timberland by county and potential productivity class, Northern Pine Unit, Minnesota, 1990

Table 6.-Area of timberland by county and stocking class of growing-stock trees, Northern Pine Unit, Minnesota, 1990

Table 7.-Area of timberland by ownership class and stocking class of growingstock trees, Northern Pine Unit, Minnesota, 1990

Table 8.-Area of timberland by forest type and ownership class, Northern Pine Unit. Minnesota, 1990

Table 9.-Area of timberland by forest type and stand-size class, Northern Pine Unit, Minnesota, 1990
Table 10.-Number of all live trees on timberland by species group and diameter class, Northern Pine Unit, Minnesota, 1990

Table 11.-Number of growing-stock trees on timberland by species group and diameter class, Northern Pine Unit, Minnesota, 1990

Table 12.- Net volume of timber on timberland by class of timber and species group, Northern Pine Unit, Minnesota, 1990

Table 13.-Net volume of growing-stock trees on timberland by species group and diameter class, Northern Pine Unit, Minnesota, 1990

Table 14.-Net volume of growing stock in the saw-log portion of sawtimber trees on timberland by species group and diameter class, Northern Pine Unit, Minnesota, 1990

Table 15.-Net volume of sawtimber trees on timberland by species group and diameter class, Northern Pine Unit, Minnesota, 1990

Table 16.-Net volume of growing-stock and sawtimber trees on timberland by county and species group, Northern Pine Unit, Minnesota, 1990

Table 17.-Net volume of live and growing-stock trees on timberland by ownership class and species group, Northern Pine Unit, Minnesota, 1990

Table 18.-Net volume of sawtimber trees on timberland by species group and butt log grade, Northern Pine Unit, Minnesota, 1990

Table 19.-Average net annual growth of growing stock and sawtimber on timberland by county and species group, Northern Pine Unit, Minnesota, 1977-1989 
Table 20.-Average annual removals of growing stock and sawtimber on timberland by county and species group. Northern Pine Unit, Minnesota. 1977-1989

Table 21.-Average net annual growth, mortality, and removals of growing stock and sawtimber on timberland by species group, Northern Pine Unit, Minnesota, 1977-1989

Table 22.-Average net annual growth and average annual removals of growing stock on timberland by ownership class and species group. Northern Pine Unit, Minnesota, 1977-1989
Table 23.-Average net annual growth and average annual removals of sawtimber on timberland by ownership class and species group. Northern Pine Unit, Minnesota, 1977-1989

Table 24.-Current annual growth, mortality, and removals of growing stock and sawtimber on timberland by species group. Northern Pine Unit, Minnesota, 1989 
Table 1.--Area of land by county and major land-use class, Northern Pine Unit, Minnesota, 1990

(In thousand acres)

\begin{tabular}{|c|c|c|c|c|c|c|}
\hline \multirow[b]{2}{*}{ County } & \multirow[b]{2}{*}{$\begin{array}{c}\text { Land } \\
\text { area }\end{array}$} & \multicolumn{5}{|c|}{ Forest land } \\
\hline & & $\begin{array}{c}\text { All } \\
\text { torest } \\
\text { land } \\
\end{array}$ & $\begin{array}{c}\text { Timber- } \\
\text { land } \\
\end{array}$ & $\begin{array}{l}\text { Timberland } \\
\text { as a percent } \\
\text { of land area }\end{array}$ & $\begin{array}{c}\text { Other } \\
\text { forest } \\
\text { land }\end{array}$ & $\begin{array}{c}\text { Reserved } \\
\text { forest } \\
\text { land }\end{array}$ \\
\hline Aitkin & $1,173.6$ & 760.2 & 710.9 & 60.6 & 50.4 & 1.0 \\
\hline Becker & 839.7 & 335.3 & 332.3 & 39.6 & 2.6 & 3.0 \\
\hline Beltrami & $1,604.5$ & 929.7 & 841.8 & 52.5 & 85.0 & 2.9 \\
\hline Cass & $1,301.2$ & 868.6 & 841.6 & 64.7 & 28.0 & 1.6 \\
\hline Clearwater & 639.7 & 321.7 & 289.4 & 45.2 & 16.1 & 18.7 \\
\hline Crow Wing & 644.8 & 388.9 & 386.7 & 60.0 & 4.8 & -- \\
\hline Hubbard & 598.8 & 407.9 & 399.8 & 66.8 & 2.2 & 5.9 \\
\hline ltasca & $1,703.4$ & $1,362.4$ & $1,324.4$ & 77.8 & 41.8 & 0.8 \\
\hline Lake of the Woods & 829.6 & 500.3 & 398.4 & 48.0 & 104.1 & -- \\
\hline Mahnomen & 357.8 & 116.6 & 113.9 & 31.8 & 1.1 & 1.6 \\
\hline Roseau & $1,073.3$ & 225.7 & 217.2 & 20.2 & 9.8 & -. \\
\hline Wadena & 344.1 & 119.1 & 119.1 & 34.6 & -. & $\cdots$ \\
\hline All counties & $11,110.5$ & $6,336.4$ & $5,975.5$ & 53.8 & 345.9 & 35.5 \\
\hline
\end{tabular}



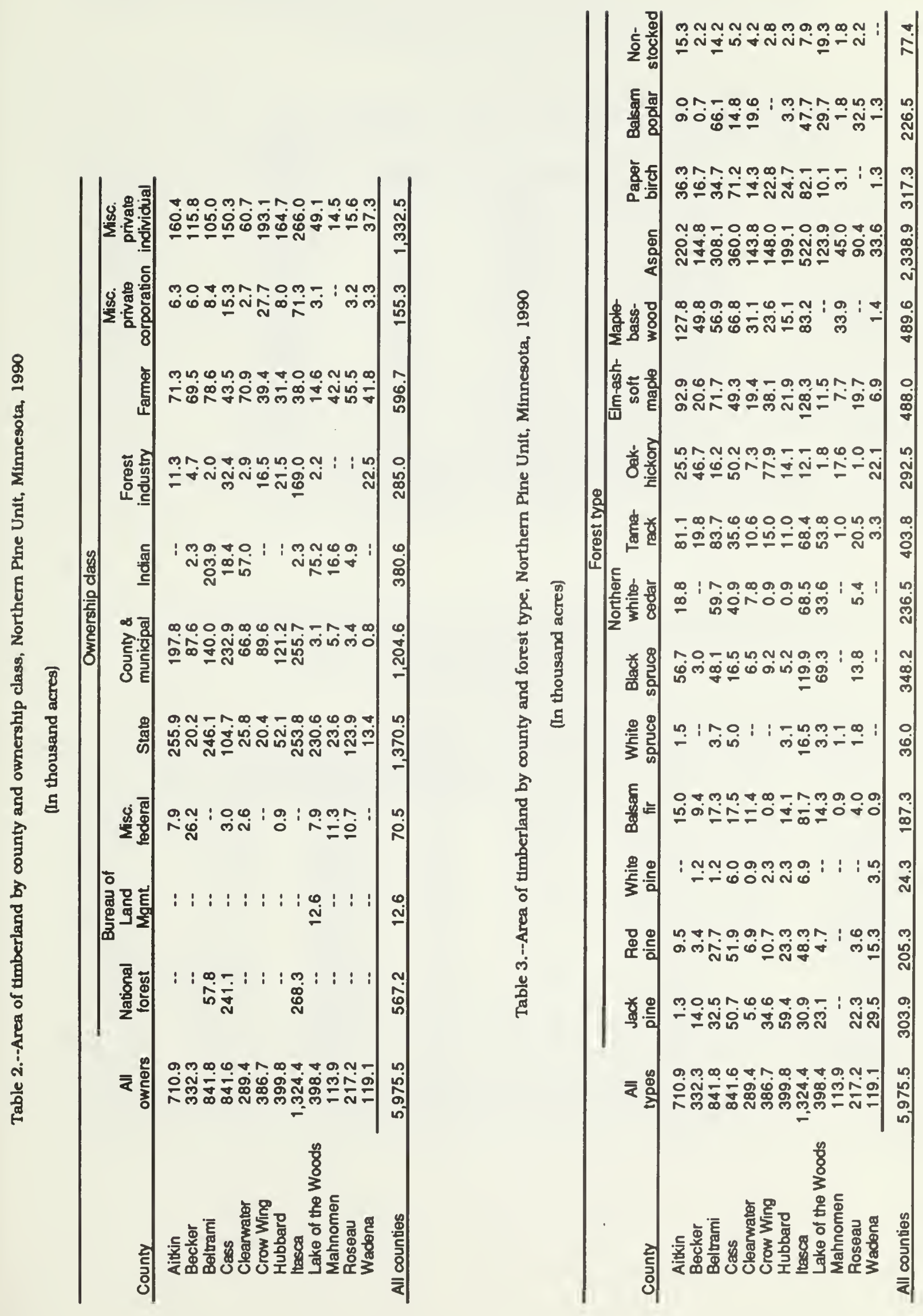
Table 4.--Area of timberland by county and stand-size class, Northern Pine Unit, Minnesota, 1990

(In thousand acres)

\begin{tabular}{|c|c|c|c|c|c|}
\hline \multirow[b]{2}{*}{ County } & \multirow[b]{2}{*}{$\begin{array}{c}\text { All } \\
\text { stands }\end{array}$} & \multicolumn{4}{|c|}{ Stand-size class } \\
\hline & & Sawtimber & Poletimber & $\begin{array}{c}\text { Seedling \& } \\
\text { sapling } \\
\end{array}$ & Nonstocked \\
\hline Aitkin & 710.9 & 235.2 & 274.6 & 185.8 & 15.3 \\
\hline Becker & 332.3 & 141.8 & 137.0 & 51.3 & 2.2 \\
\hline Beltrami & 841.8 & 253.4 & 321.5 & 252.7 & 14.2 \\
\hline Cass & 841.6 & 319.2 & 314.3 & 202.9 & 5.2 \\
\hline Clearwater & 289.4 & 96.5 & 113.2 & 75.5 & 4.2 \\
\hline Crow Wing & 386.7 & 159.2 & 146.2 & 78.5 & 2.8 \\
\hline Hubbard & 399.8 & 104.0 & 199.6 & 93.9 & 2.3 \\
\hline Itasca & $1,324.4$ & 427.4 & 432.3 & 456.8 & 7.9 \\
\hline Lake of the Woods & 398.4 & 90.6 & 142.7 & 145.8 & 19.3 \\
\hline Mahnomen & 113.9 & 30.5 & 54.3 & 27.3 & 1.8 \\
\hline Roseau & 217.2 & 49.9 & 76.9 & 88.2 & 2.2 \\
\hline Wadena & 119.1 & 34.4 & 43.6 & 41.1 & -- \\
\hline All counties & $5,975.5$ & $1,942.1$ & $2,256.2$ & $1,699.8$ & 77.4 \\
\hline
\end{tabular}

Table 5.--Area of timberland by county and potential productivity class, Northern Pine Unit, Minnesota, 1990

(In thousand acres)

\begin{tabular}{|c|c|c|c|c|c|c|}
\hline \multirow[b]{2}{*}{ County } & \multirow{2}{*}{$\begin{array}{c}\text { All } \\
\text { classes }\end{array}$} & \multicolumn{5}{|c|}{$\begin{array}{c}\text { Potential productivity class } \\
\text { (cubic feet of growth per acre per year) }\end{array}$} \\
\hline & & $165+$ & $120-164$ & $85-119$ & $50-84$ & $20-49$ \\
\hline Aitkin & 710.9 & -- & 6.1 & 130.8 & 138.7 & 435.3 \\
\hline Becker & 332.3 & -- & 1.0 & 56.3 & 103.3 & 171.7 \\
\hline Beltrami & 841.8 & -- & 7.6 & 127.7 & 191.8 & 514.7 \\
\hline Cass & 841.6 & 1.5 & 15.1 & 193.4 & 270.3 & 361.3 \\
\hline Clearwater & 289.4 & - & 3.6 & 76.9 & 73.7 & 135.2 \\
\hline Crow Wing & 386.7 & .- & -. & 35.8 & 163.0 & 187.9 \\
\hline Hubbard & 399.8 & -- & 4.8 & 85.1 & 149.0 & 160.9 \\
\hline Itasca & $1,324.4$ & 1.6 & 26.7 & 385.6 & 266.4 & 644.1 \\
\hline Lake of the Woods & 398.4 & -- & -. & 36.5 & 84.0 & 277.9 \\
\hline Mahnomen & 113.9 & -. & -- & 18.3 & 32.5 & 63.1 \\
\hline Roseau & 217.2 & -- & 1.8 & 8.7 & 63.7 & 143.0 \\
\hline Wadena & 119.1 & -. & 3.0 & 20.8 & 52.0 & 43.3 \\
\hline All counties & $5,975.5$ & 3.1 & 69.7 & $1,175.9$ & $1,588.4$ & $3,138.4$ \\
\hline
\end{tabular}


Table 6.--Area of timberland by county and stocking class of growing-stock trees ${ }^{1}$. Northern Pine Unit. Minnesota, 1990

(In thousand acres)

\begin{tabular}{|c|c|c|c|c|c|c|}
\hline \multirow[b]{2}{*}{ County } & \multirow[b]{2}{*}{$\begin{array}{c}\text { All } \\
\text { classes }\end{array}$} & \multicolumn{5}{|c|}{ Stocking class of growing-stock trees } \\
\hline & & $\begin{array}{c}\text { Non- } \\
\text { stocked }\end{array}$ & $\begin{array}{l}\text { Poorly } \\
\text { stocked }\end{array}$ & $\begin{array}{l}\text { Moderately } \\
\text { stocked }\end{array}$ & $\begin{array}{c}\text { Fully } \\
\text { stocked }\end{array}$ & $\begin{array}{c}\text { Over- } \\
\text { stocked }\end{array}$ \\
\hline $\begin{array}{l}\text { Aitkin } \\
\text { Becker } \\
\text { Beltrami } \\
\text { Cass } \\
\text { Cleanwater } \\
\text { Crow Wing } \\
\text { Hubbard } \\
\text { ltasca } \\
\text { Lake of the Woods } \\
\text { Mahnomen } \\
\text { Roseau } \\
\text { Wadena }\end{array}$ & $\begin{array}{r}710.9 \\
332.3 \\
841.8 \\
841.6 \\
289.4 \\
386.7 \\
399.8 \\
1,324.4 \\
398.4 \\
113.9 \\
217.2 \\
119.1 \\
\end{array}$ & $\begin{array}{r}18.9 \\
2.2 \\
17.1 \\
5.2 \\
5.1 \\
3.9 \\
2.3 \\
16.2 \\
27.0 \\
1.8 \\
3.6 \\
. .\end{array}$ & $\begin{array}{r}167.7 \\
71.0 \\
168.3 \\
119.8 \\
67.8 \\
76.4 \\
72.4 \\
193.8 \\
90.9 \\
18.8 \\
62.3 \\
34.1 \\
\end{array}$ & \begin{tabular}{r|}
265.1 \\
158.3 \\
305.9 \\
300.7 \\
105.3 \\
177.0 \\
174.6 \\
492.7 \\
124.9 \\
50.0 \\
70.7 \\
63.7 \\
\end{tabular} & $\begin{array}{r}176.5 \\
84.9 \\
238.1 \\
298.4 \\
81.7 \\
93.5 \\
108.6 \\
388.5 \\
106.0 \\
28.6 \\
59.7 \\
16.9 \\
\end{array}$ & $\begin{array}{r}82.7 \\
15.9 \\
112.4 \\
117.5 \\
29.5 \\
35.9 \\
41.9 \\
233.2 \\
49.6 \\
14.7 \\
20.9 \\
4.4 \\
\end{array}$ \\
\hline All counties & $5,975.5$ & 103.3 & $1,143.3$ & $2,288.9$ & $1,681,4$ & 758.6 \\
\hline
\end{tabular}

IThis table is based on the stockdng percent of growing-stock trees rather than that of all live trees. To use the definitions of stocking for this table, replace the term "live" by "growing-stock."

Table 7.--Area of timberland by ownership class and stocking class of growing-stock trees 1 . Northern PIne Unit, Minnesota, 1990

(In thousand acres)

\begin{tabular}{|c|c|c|c|c|c|c|}
\hline \multirow[b]{2}{*}{ Ownership class } & \multirow[b]{2}{*}{$\begin{array}{c}\text { All } \\
\text { classes }\end{array}$} & \multicolumn{5}{|c|}{ Stocking class of growing-stock trees } \\
\hline & & $\begin{array}{c}\text { Non- } \\
\text { stocked }\end{array}$ & $\begin{array}{c}\text { Poorly } \\
\text { stocked }\end{array}$ & $\begin{array}{l}\text { Moderately } \\
\text { stocked }\end{array}$ & $\begin{array}{c}\text { Fully } \\
\text { stocked }\end{array}$ & $\begin{array}{l}\text { Over- } \\
\text { stocked }\end{array}$ \\
\hline National forest & 567.2 & 2.4 & 43.9 & 157.4 & 224.2 & 139.3 \\
\hline Bureau of Land Mgmt. & 12.6 & 1.1 & 4.4 & 4.4 & 2.7 & -. \\
\hline Miscollaneous federal & 70.5 & 1.8 & 18.5 & 35.8 & 11.1 & 3.3 \\
\hline State & $1,370.5$ & 50.0 & 288.2 & 446.5 & 386.7 & 199.1 \\
\hline County and municipal & $1,204.6$ & 15.6 & 210.6 & 467.3 & 343.2 & 167.9 \\
\hline Indian & 380.6 & 11.8 & 86.1 & 139.0 & 91.5 & 52.2 \\
\hline Forest Industry & 285.0 & 3.1 & 51.3 & 113.7 & 82.1 & 34.8 \\
\hline Farmer & 596.7 & 11.0 & 157.1 & 277.2 & 117.7 & 33.7 \\
\hline Miscellaneous & 1553 & $\ldots$ & 295 & 60.0 & 477 & 18.1 \\
\hline $\begin{array}{l}\text { private corporation } \\
\text { Miscellaneus }\end{array}$ & & & & & & \\
\hline $\begin{array}{l}\text { Miscellaneous } \\
\text { private individual }\end{array}$ & $1,332.5$ & 6.5 & 253.7 & 587.6 & 374.5 & 110.2 \\
\hline All owners & $5,975.5$ & 103.3 & $1,143.3$ & $2,288.9$ & $1,681.4$ & 758.6 \\
\hline
\end{tabular}

${ }^{1}$ This table is based on the stocking percent of growing-stock trees rather than that of all itve trees. To use the definitjons of stocking for this table, replace the term "live" by "growing-stock." 


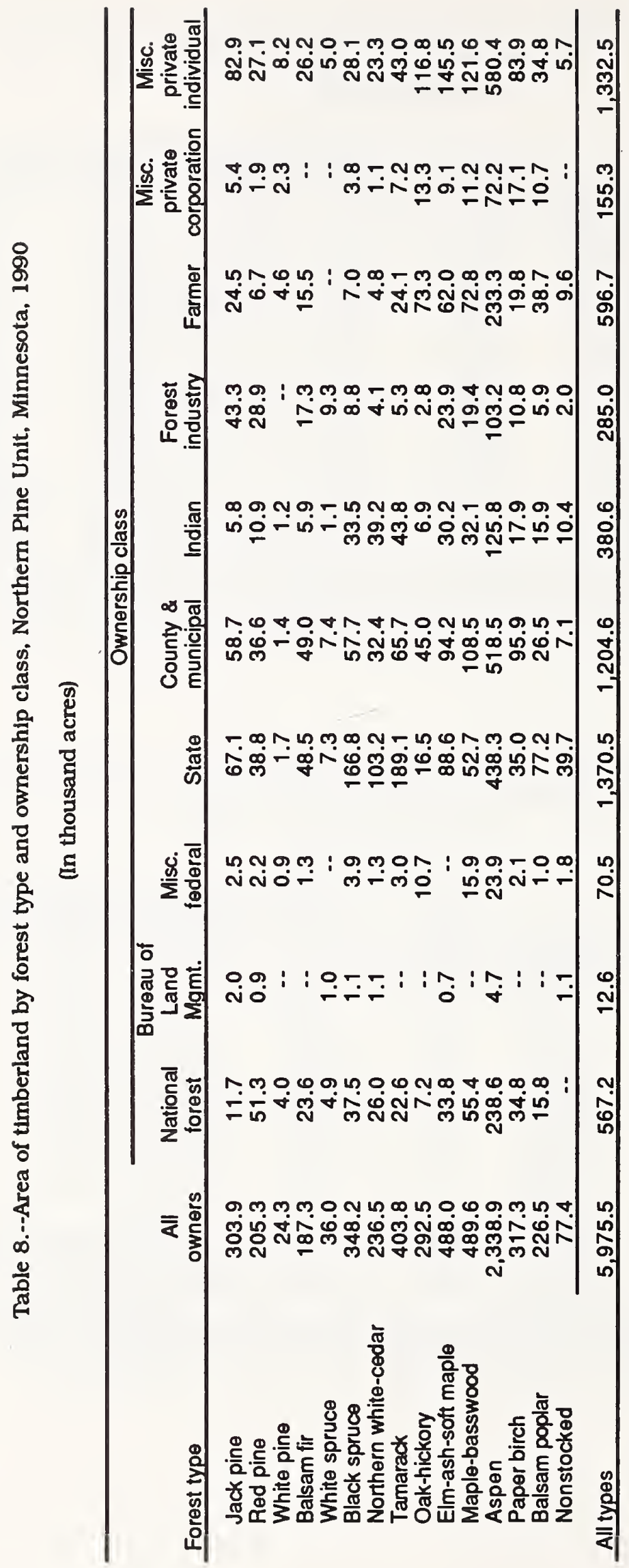


Table 9.--Area of timberland by forest type and stand-size class,

Northern Pine Unit, Minnesota, 1990

(In thousand acres)

\begin{tabular}{|c|c|c|c|c|c|}
\hline \multirow[b]{2}{*}{ Forest type } & \multirow[b]{2}{*}{$\begin{array}{c}\text { All } \\
\text { stands }\end{array}$} & \multicolumn{4}{|c|}{ Stand-size class } \\
\hline & & Sawtimber & Poletimber & $\begin{array}{l}\text { Sapling \& } \\
\text { seedling }\end{array}$ & Nonstocked \\
\hline Jack pine & 290.7 & 127.2 & 115.5 & 48.0 & - \\
\hline Red pine & 167.0 & 94.1 & 39.7 & 33.2 & $\cdots$ \\
\hline White pine & 24.3 & 18.4 & 5.9 & -- & -- \\
\hline Balsam fir & 180.2 & 55.2 & 75.5 & 49.5 & -- \\
\hline White spruce & 27.4 & 7.7 & 10.3 & 9.4 & -. \\
\hline Black spruce & 348.2 & 19.9 & 105.7 & 222.6 & -. \\
\hline Northern white-cedar & 236.5 & 90.5 & 120.3 & 25.7 & -- \\
\hline Tamarack & 403.8 & 48.9 & 170.8 & 184.1 & - \\
\hline Oak-hickory & 305.2 & 126.7 & 133.1 & 45.4 & $\cdots$ \\
\hline Elm-ash-soft maple & 489.6 & 141.4 & 206.0 & 142.2 & -. \\
\hline Maple-basswood & 495.3 & 267.3 & 185.4 & 42.6 & - \\
\hline Aspen & $2,379.2$ & 802.4 & 810.5 & 766.3 & - \\
\hline Paper birch & 321.2 & 86.4 & 195.9 & 38.9 & -. \\
\hline Balsam poplar & 229.5 & 56.0 & 81.6 & 91.9 & $\ldots$ \\
\hline Nonstocked & 77.4 & -. & .. & - & 77.4 \\
\hline All types & $5,975.5$ & $1,942.1$ & $2,256.2$ & $1,699.8$ & 77.4 \\
\hline
\end{tabular}




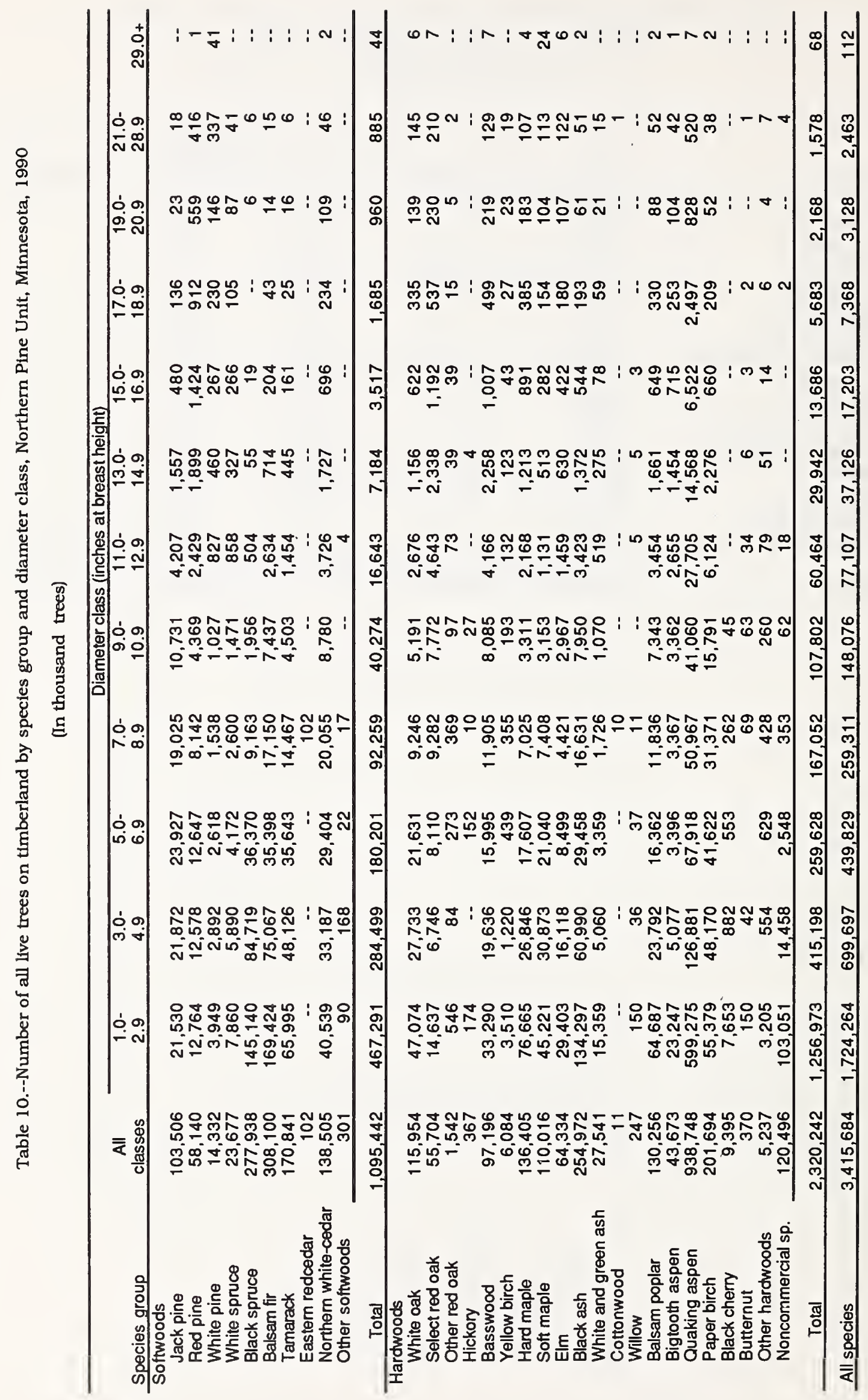




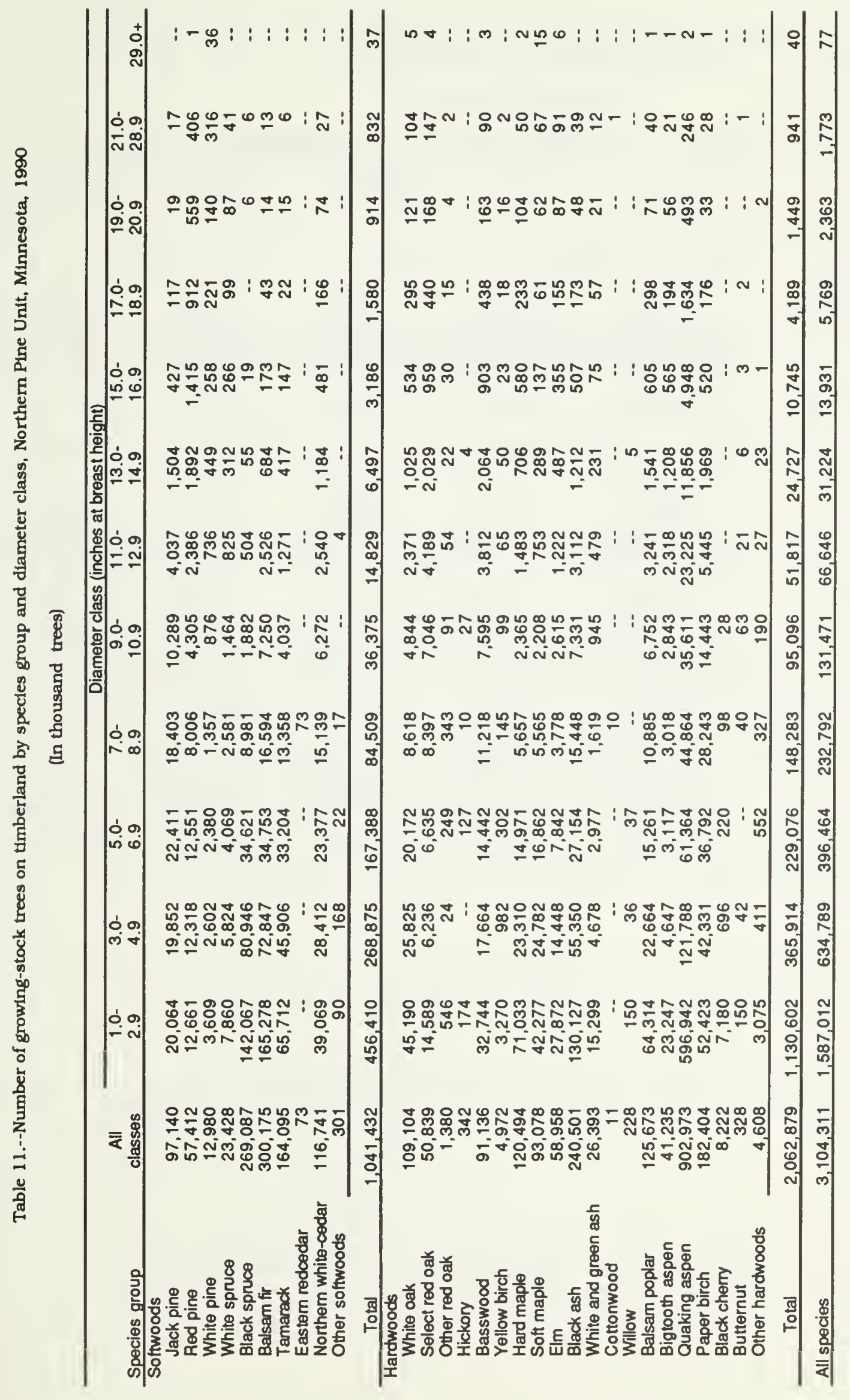


Table 12.--Net volume of timber on timberland by class of timber and species group, Northern Pine Unit, Minnesota, 1990

(In thousand cubic feet)

\begin{tabular}{|c|c|c|c|c|c|}
\hline \multirow[b]{2}{*}{ Class of timber } & \multirow[b]{2}{*}{$\begin{array}{c}\text { All } \\
\text { species }\end{array}$} & \multicolumn{4}{|c|}{ Species group } \\
\hline & & Pine & $\begin{array}{c}\text { Other } \\
\text { softwoods }\end{array}$ & $\begin{array}{c}\text { Soft } \\
\text { hardwoods }\end{array}$ & $\begin{array}{c}\text { Hard } \\
\text { hardwoods }\end{array}$ \\
\hline \multicolumn{6}{|l|}{$\begin{array}{l}\text { Live trees } \\
\text { Growing-stock trees } \\
\text { Sawtimber }\end{array}$} \\
\hline $\begin{array}{l}\text { Saw-log portion } \\
\text { Upper stem portion }\end{array}$ & $\begin{array}{r}2,455,132 \\
731,948\end{array}$ & $\begin{array}{r}526,375 \\
68,039\end{array}$ & $\begin{array}{r}389,958 \\
60,769\end{array}$ & $\begin{array}{r}1,191,898 \\
464,657\end{array}$ & $\begin{array}{l}346,901 \\
138,483\end{array}$ \\
\hline Total & $3,187,080$ & 594,414 & 450,727 & $1,656,555$ & 485,384 \\
\hline Poletimber & $3,399,269$ & 240,887 & 658,353 & $1,870,567$ & 629,462 \\
\hline All growing-stock trees & $6,586,349$ & 835,301 & $1,109,080$ & $3,527,122$ & $1,114,846$ \\
\hline \multicolumn{6}{|l|}{ Cull trees } \\
\hline $\begin{array}{l}\text { Short-log trees } \\
\text { Rough trees }\end{array}$ & 87,998 & 3,691 & 9,366 & 52,733 & 22,208 \\
\hline $\begin{array}{l}\text { Sawtimber } \\
\text { Poletimber }\end{array}$ & $\begin{array}{l}161,973 \\
255,431 \\
\end{array}$ & $\begin{array}{l}9,105 \\
7,265\end{array}$ & $\begin{array}{l}21,494 \\
38,505 \\
\end{array}$ & $\begin{array}{r}88,740 \\
148,712 \\
\end{array}$ & $\begin{array}{l}42,634 \\
60,949\end{array}$ \\
\hline Total & 417,404 & 16,370 & 59,999 & 237,452 & 103,583 \\
\hline \multicolumn{6}{|l|}{ Rotten trees } \\
\hline Sawtimber & 132,996 & $\begin{array}{r}1,899 \\
26 ?\end{array}$ & $\begin{array}{r}17,337 \\
7310\end{array}$ & 94,031 & $\begin{array}{r}19,729 \\
5\end{array}$ \\
\hline $\begin{array}{l}\text { Poletmoer } \\
\text { Total }\end{array}$ & $\frac{41,105}{174.101}$ & $\frac{262}{2.161}$ & $\frac{1,219}{24.556}$ & $\frac{27,896}{121,927}$ & $\frac{5,728}{25,457}$ \\
\hline All cull trees & 679,503 & 22,222 & 93,921 & 412,112 & 151,248 \\
\hline All live trees & $7,265,852$ & 857,523 & $1,203,001$ & $3,939,234$ & $1,266,094$ \\
\hline \multicolumn{6}{|l|}{ Salvable dead trees } \\
\hline Sawtimber & 46,407 & 5,677 & 12,263 & 27,615 & 852 \\
\hline Poltetimber & 34,102 & 2,641 & 8,275 & 20,686 & 2,500 \\
\hline Total & 80,509 & 8,318 & 20,538 & 48,301 & 3,352 \\
\hline All classes of timber & $7,346,361$ & 865,841 & $1,223,539$ & $3,987,535$ & $1,269,446$ \\
\hline
\end{tabular}




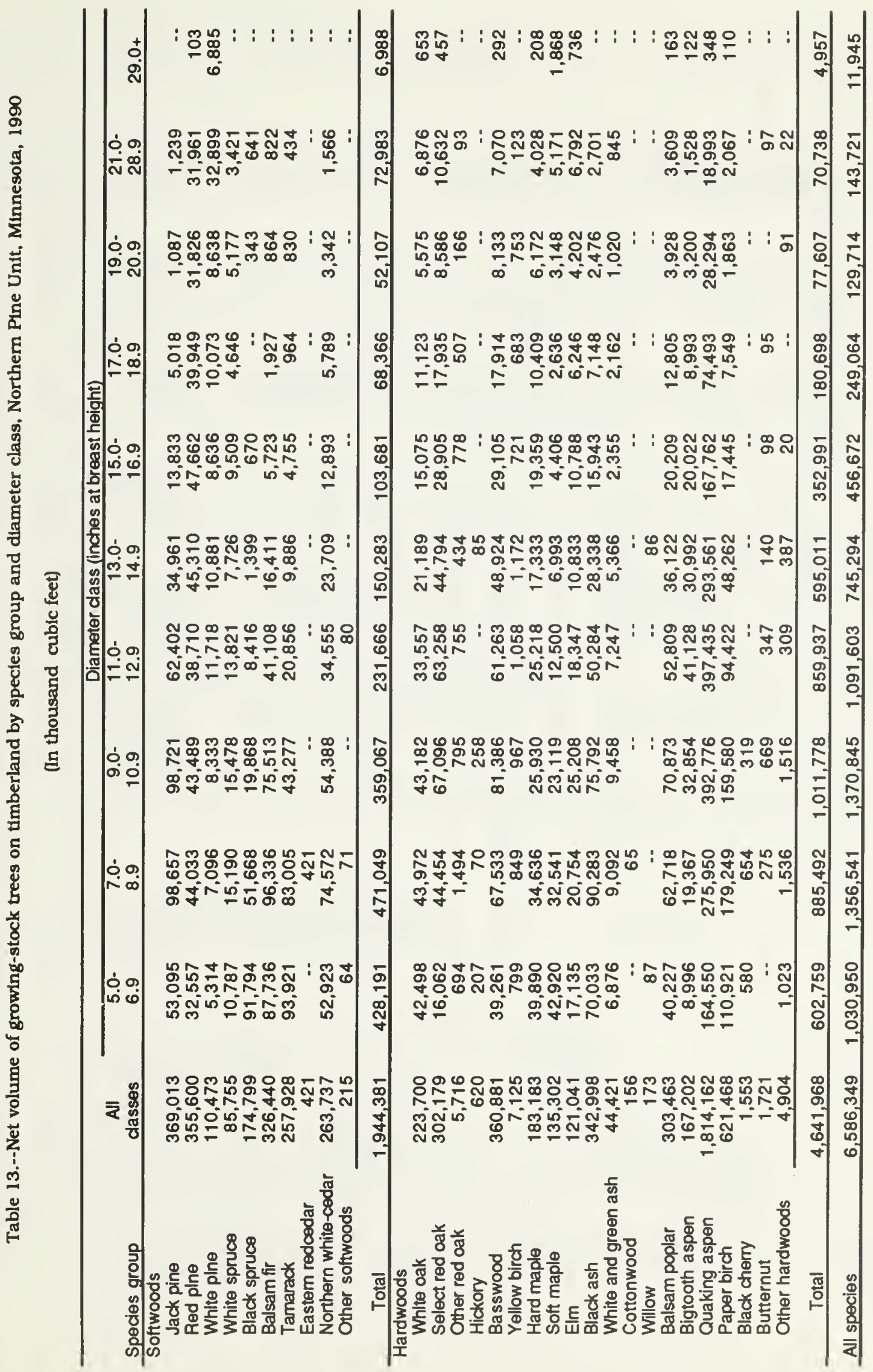




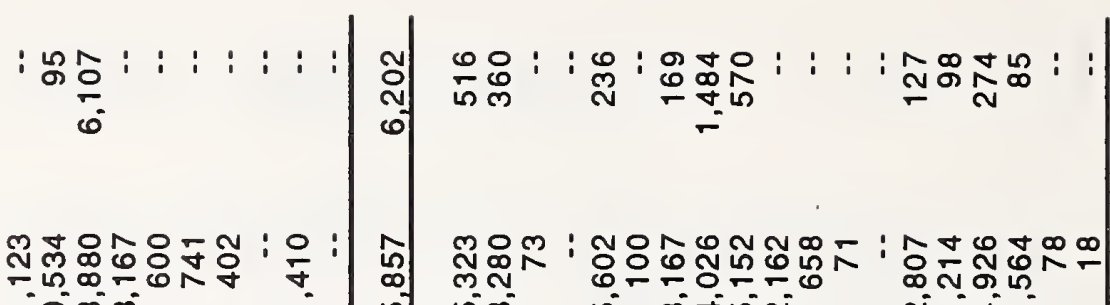
नूत्ला =

is $\infty^{\circ}$

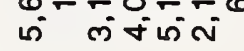

iั

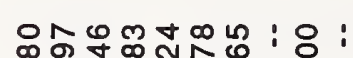

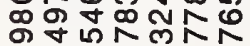

ลंก

ले

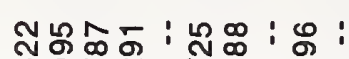

ind

옹

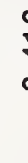

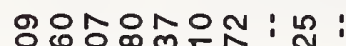

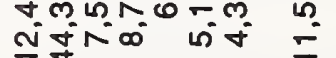

\section{m}

离

:

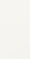

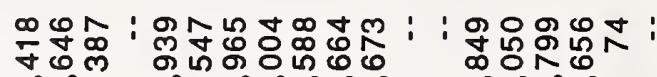

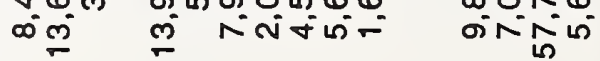

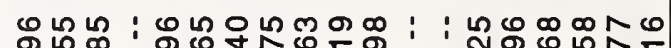

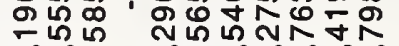

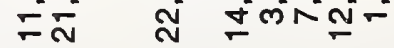

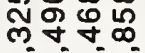

กำ

$0000-00: 0:$

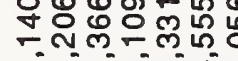

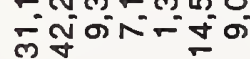

$\frac{n}{0}$

年

$\sin$

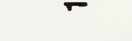

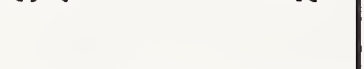

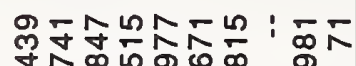

马N

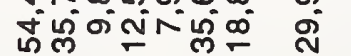

กิ

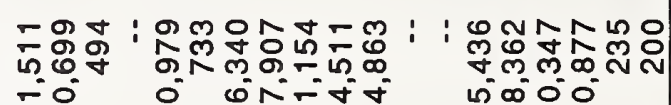

ì

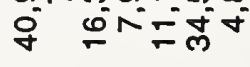

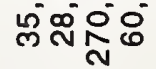

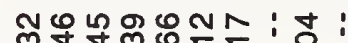

ल्లె

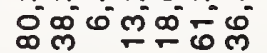
,

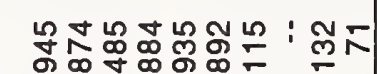
(1)

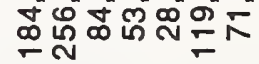

๘

ल्ल

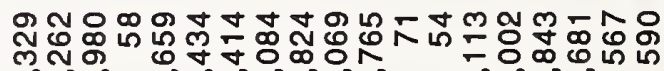

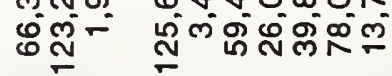

รัฒ

인 한

กิ่

의

งิ

ถึ่ ลิ-

ज

-

ัํำ

䎡 总

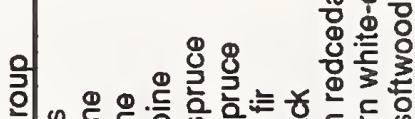

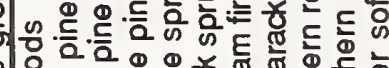

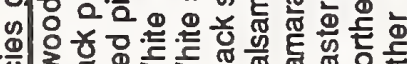

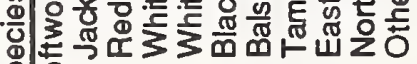
कीजि

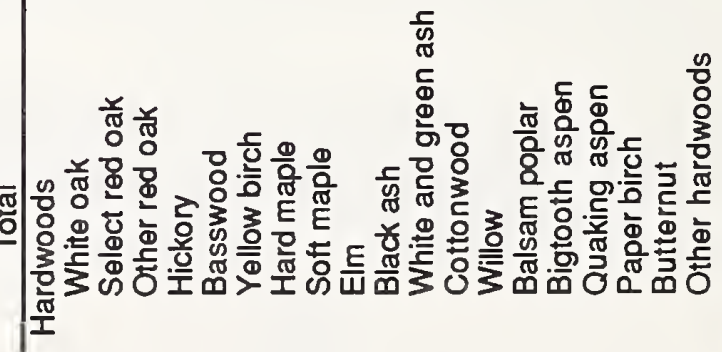

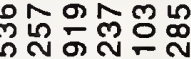
กำ 


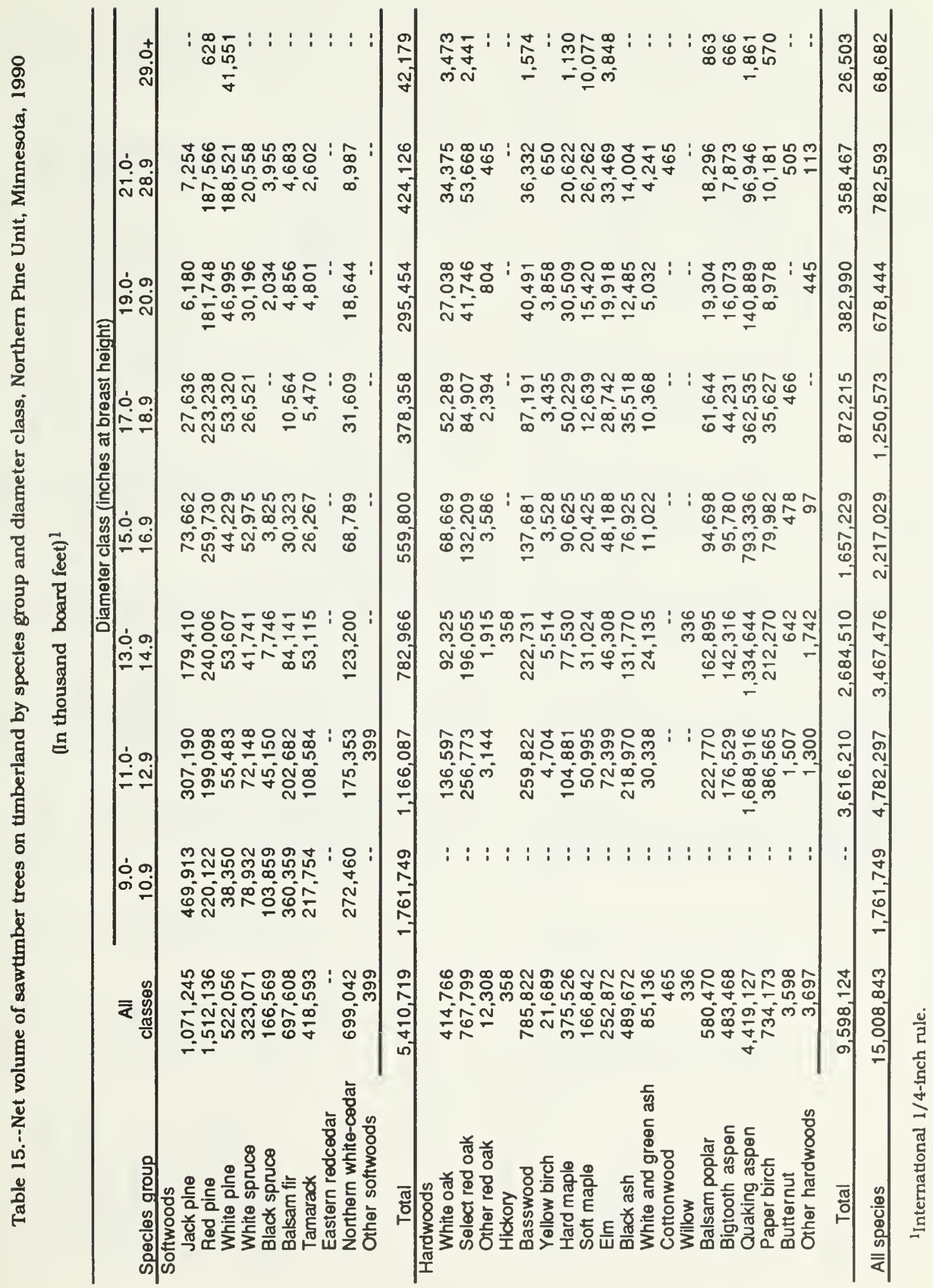



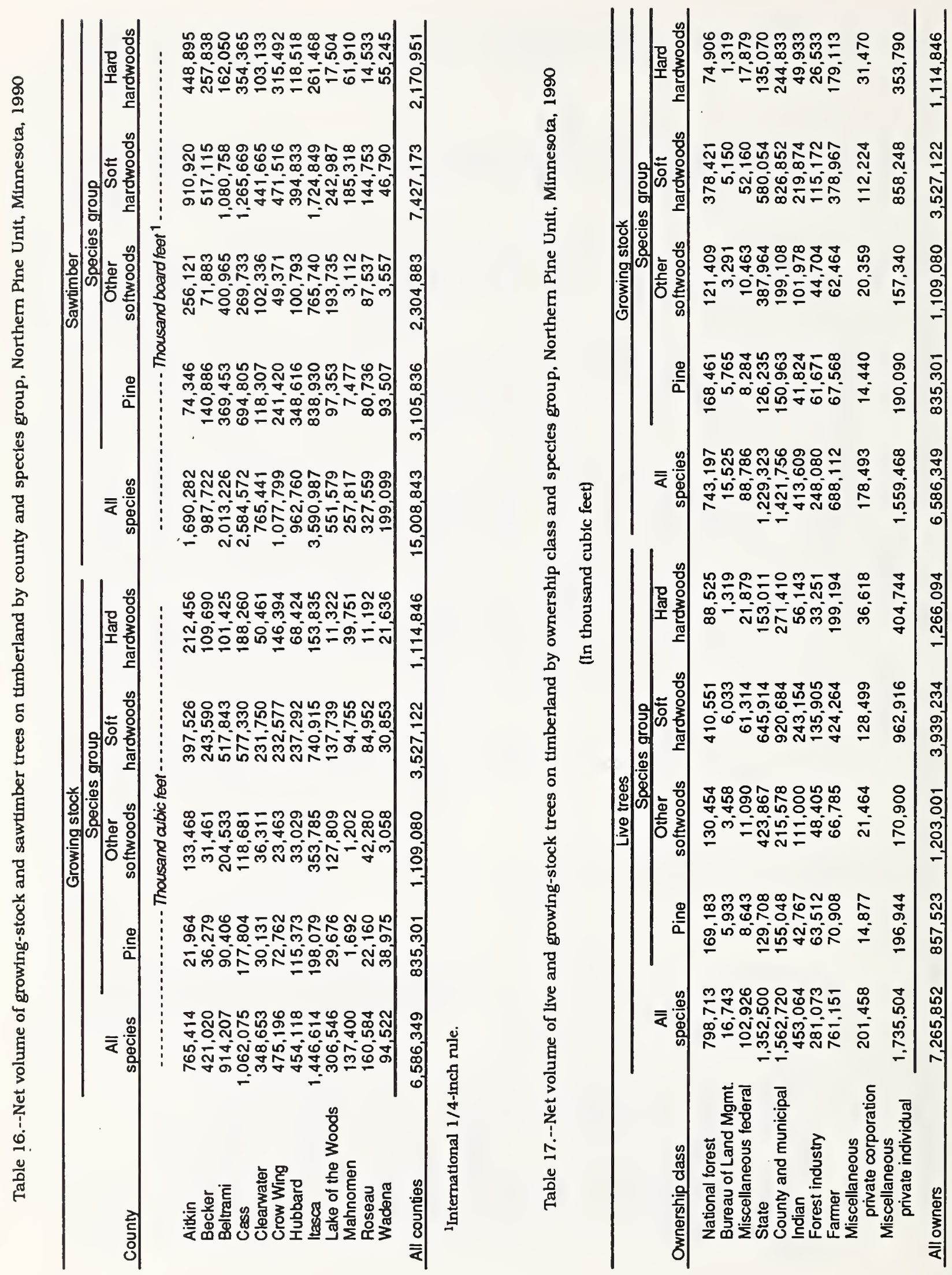
Table 18.--Net volume of sawtimber trees on timberland by species group and butt log grade. Northern Pine Unit. Minnesota. 1990

(In thousand board feet) 1

\begin{tabular}{|c|c|c|c|c|c|}
\hline \multirow[b]{2}{*}{ Species group } & \multirow{2}{*}{$\begin{array}{c}\text { All } \\
\text { grades }\end{array}$} & \multicolumn{4}{|c|}{ Butt log grade } \\
\hline & & $\overline{1}$ & 2 & 3 & $T i \theta$ and timber \\
\hline \multicolumn{6}{|l|}{ Softwoods } \\
\hline Jack pine & $1,071,245$ & 1,548 & 68,523 & $1,001,174$ & -- \\
\hline Red pine & $1,512,136$ & 169,224 & 329,370 & $1,012,541$ & 1,001 \\
\hline White pine & 522,056 & 83,468 & 143,109 & 199,850 & 95,629 \\
\hline White spruce & 323,071 & 5,323 & 36,099 & 279,368 & 2,281 \\
\hline Black spruce & 166,569 & .. & 6,309 & 160,260 & .. \\
\hline Balsam fir & 697,608 & .. & 15,277 & 682,331 & -. \\
\hline Tamarack & 418,593 & .. & 18,993 & 399,600 & .. \\
\hline Eastern redcedar & & -. & -. & 662,452 & 6,967 \\
\hline Northern white-cedar & 699,042 & 1,676 & 27,947 & .. & -. \\
\hline Other softwoods & 399 & $\therefore$ & $\ldots$ & 399 & .. \\
\hline Total & $5,410,719$ & 261,239 & 645,627 & $4,397,975$ & 105,878 \\
\hline \multicolumn{6}{|l|}{ Hardwoods } \\
\hline White oak & 414,766 & 20,588 & 83,470 & 266,864 & 43,844 \\
\hline Select red oak & 767,799 & 33,095 & 157,600 & 524,831 & 52,273 \\
\hline Other red oak & 12,308 & .. & .. & 10,319 & 1,989 \\
\hline Hickory & 358 & -. & -. & 358 & \\
\hline Basswood & 785,822 & 150,034 & 262,270 & 362,656 & 10,862 \\
\hline Yellow birch & 21,689 & 2,333 & 4,743 & 12,696 & 1,917 \\
\hline Hard maple & 375,526 & 64,968 & 148,359 & 153,685 & 8,514 \\
\hline Soft maple & 166,842 & 33,803 & 41,253 & 90,683 & 1,103 \\
\hline Elm & 252,872 & 14,131 & 81,771 & 156,970 & -- \\
\hline Black ash & 489,672 & 52,828 & 153,181 & 273,949 & 9,714 \\
\hline White and green ash & 85,136 & 6,872 & 23,634 & 53,177 & 1,453 \\
\hline Cottonwood & 465 & -. & -. & 465 & - \\
\hline Willow & 336 & -. & -. & 336 & -- \\
\hline Balsam poplar & 580,470 & 19,495 & 89,902 & 440,330 & 30,743 \\
\hline Bigtooth aspen & 483,468 & 22,711 & 107,310 & 339,321 & 14,126 \\
\hline Quaking aspen & $4,419,127$ & 134,588 & 716,608 & $3,301,590$ & 266,341 \\
\hline Paper birch & 734,173 & 34,421 & 147,282 & 516,729 & 35,741 \\
\hline Butternut & 3,598 & 2,494 & -. & 1,104 & -. \\
\hline Other hardwoods & 3,697 & -. & $\ldots$ & 3,697 & -. \\
\hline Total & $9,598,124$ & 592,361 & $2,017,383$ & $6,509,760$ & 478,620 \\
\hline All species & $15,008,843$ & 853,600 & $2,663,010$ & $10,907,735$ & 584,498 \\
\hline
\end{tabular}

${ }^{1}$ International 1/4-inch rule. 

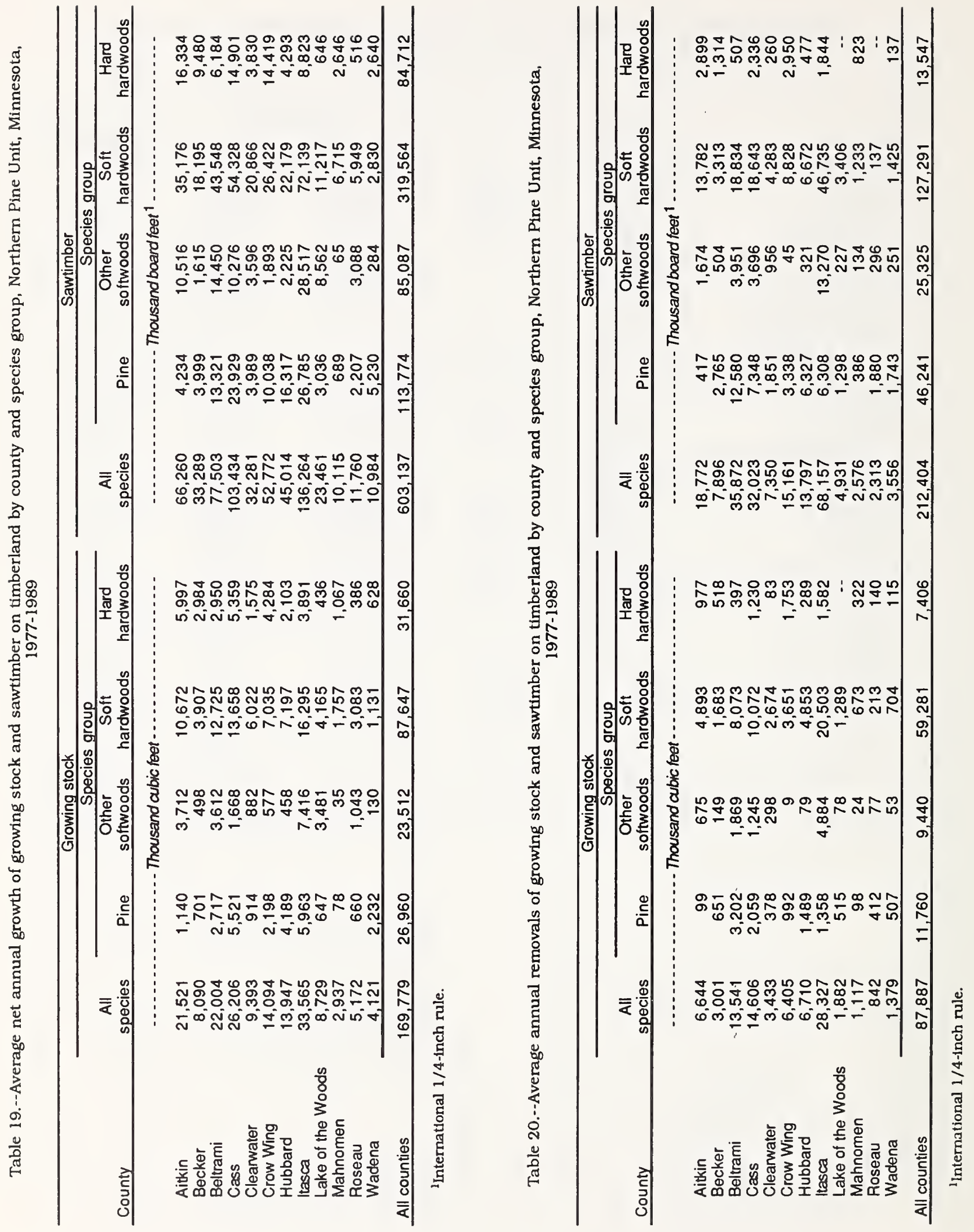
Table 21.--Average net annual growth, mortality, and removals of growing stock and sawtimber on timberland by species group, Northern Pine Unit, Minnesota, 1977-1989

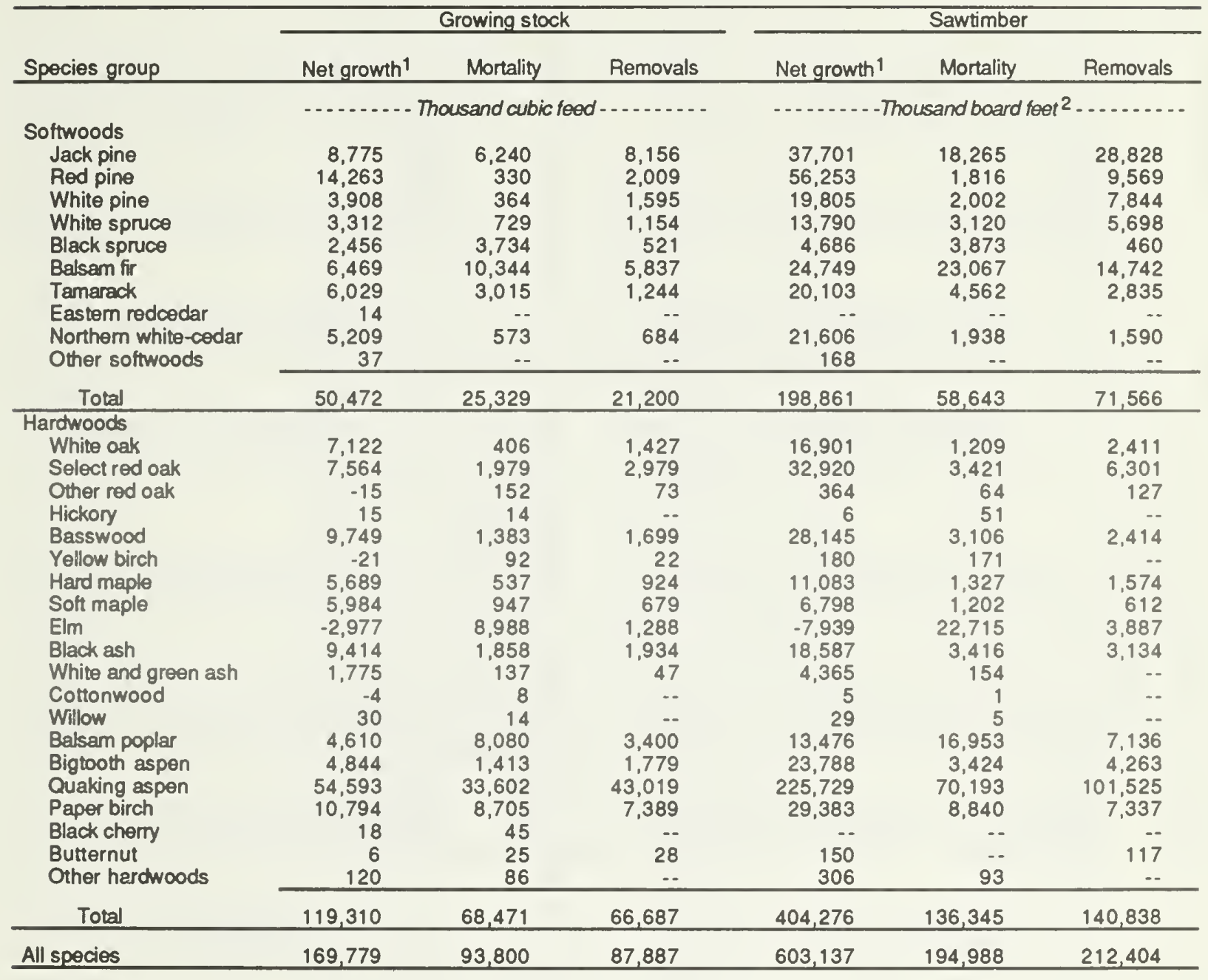

${ }^{1}$ An estlmate of average gross growth may be computed by adding average mortality to average net growth.

2 International 1/4-inch rule. 

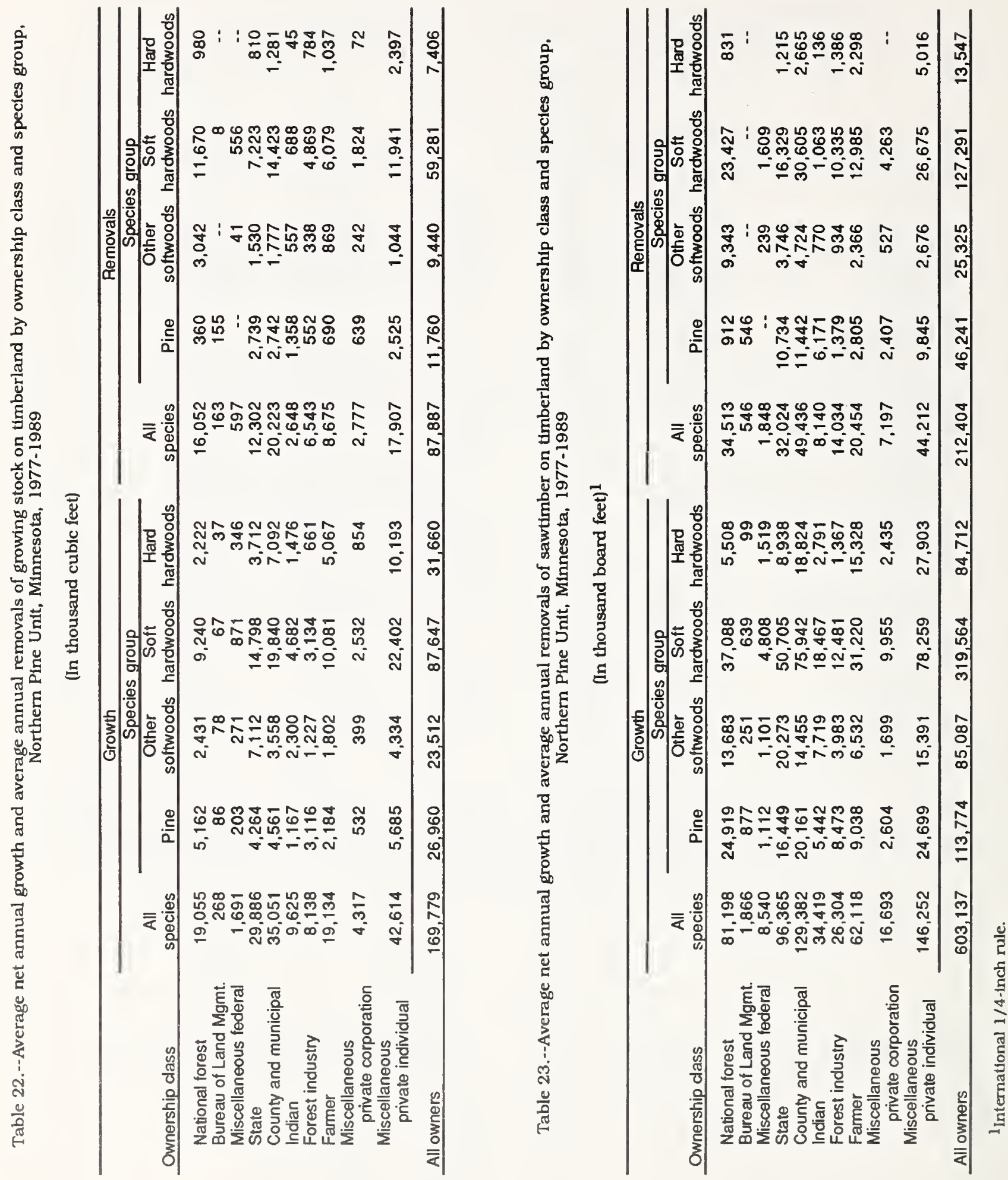
Table 24.--Current annual growth, mortality, and removals of growing stock and sawtimber on timberland by species group, Northern Pine Unit, Minnesota, 1989

\begin{tabular}{|c|c|c|c|c|c|c|}
\hline \multirow[b]{2}{*}{ Species group } & \multicolumn{3}{|c|}{ Growing stock } & \multicolumn{3}{|c|}{ Sawtimber } \\
\hline & $\begin{array}{c}1989 \\
\text { Net growth } 1\end{array}$ & $\begin{array}{c}1989 \\
\text { Mortality }\end{array}$ & $\begin{array}{c}1988 \\
\text { Removals } 2 \\
\end{array}$ & $\begin{array}{c}1989 \\
\text { Net growth } 1\end{array}$ & $\begin{array}{c}1989 \\
\text { Mortality }\end{array}$ & $\begin{array}{c}1988 \\
\text { Removals } \\
\end{array}$ \\
\hline & \multicolumn{3}{|c|}{. . . . Thousand cubic foet $\ldots \ldots$} & \multicolumn{3}{|c|}{. . . Thousand board foet ${ }^{3} \ldots \ldots$} \\
\hline $\begin{array}{l}\text { Jack pine } \\
\text { Red pine } \\
\text { White pine } \\
\text { Spruce } \\
\text { Batsam fir } \\
\text { Tamarack } \\
\text { Cedar } \\
\text { Other softwoods }\end{array}$ & $\begin{array}{r}8,667 \\
17,266 \\
5,610 \\
8,287 \\
9,446 \\
7,016 \\
5,951 \\
28 \\
\end{array}$ & $\begin{array}{r}6,668 \\
74 \\
87 \\
3,967 \\
8,617 \\
2,732 \\
315 \\
2 \\
\end{array}$ & $\begin{array}{r}8,911 \\
6,346 \\
1,641 \\
2,660 \\
5,897 \\
311 \\
1,594 \\
. \\
\end{array}$ & $\begin{array}{r}42,367 \\
65,821 \\
28,140 \\
26,284 \\
42,571 \\
27,233 \\
22,422 \\
1 \\
\end{array}$ & $\begin{array}{r}20,115 \\
938 \\
1,052 \\
5,347 \\
17,448 \\
3,538 \\
2,065 \\
15 \\
\end{array}$ & $\begin{array}{r}33,139 \\
31,079 \\
9,075 \\
6,639 \\
14,957 \\
548 \\
1,493 \\
-- \\
\end{array}$ \\
\hline Total & 62,271 & 26,813 & 27,360 & 254,839 & 95,533 & 96,930 \\
\hline $\begin{array}{l}\text { Hardwoods } \\
\text { White oak } \\
\text { Red oak } \\
\text { Basswood } \\
\text { Yellow birch } \\
\text { Hard maple } \\
\text { Soft maple } \\
\text { Elm } \\
\text { Ash } \\
\text { Cottonwood } \\
\text { Balsam poplar } \\
\text { Aspen } \\
\text { Paper birch } \\
\text { Other hardwoods }\end{array}$ & $\begin{array}{r}8,857 \\
9,328 \\
11,655 \\
88 \\
7,187 \\
7,815 \\
2,067 \\
13,606 \\
3 \\
8,204 \\
66,469 \\
14,394 \\
342 \\
\end{array}$ & $\begin{array}{r}8 \\
2,098 \\
1,591 \\
120 \\
589 \\
1,797 \\
3,952 \\
2,295 \\
1 \\
7,028 \\
38,853 \\
8,621 \\
228 \\
\end{array}$ & $\begin{array}{r}819 \\
2,834 \\
1,128 \\
44 \\
437 \\
506 \\
847 \\
1,355 \\
228 \\
1,502 \\
76,412 \\
3,962 \\
51 \\
\end{array}$ & $\begin{array}{r}21,516 \\
40,889 \\
32,520 \\
36 \\
12,630 \\
10,145 \\
4,825 \\
30,352 \\
5 \\
25,612 \\
288,131 \\
40,095 \\
833 \\
\end{array}$ & $\begin{array}{r}211 \\
4,322 \\
4,313 \\
363 \\
1,773 \\
1,507 \\
9,483 \\
4,003 \\
1 \\
14,772 \\
92,286 \\
9,441 \\
155 \\
\end{array}$ & $\begin{array}{r}1,872 \\
8,937 \\
5,272 \\
208 \\
989 \\
1,017 \\
2,927 \\
5,372 \\
141 \\
3,107 \\
216,946 \\
12,733 \\
183 \\
\end{array}$ \\
\hline Total & 150,015 & 67,181 & 90,125 & 507,589 & 142,630 & 259,704 \\
\hline All spocies & 212,286 & 93,994 & 117,485 & 762,428 & 238,163 & 356,634 \\
\hline
\end{tabular}

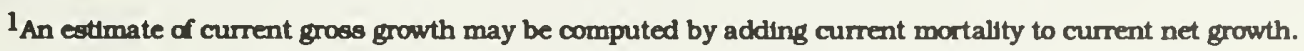

${ }^{2}$ Based on data from a 1988 mill survey and a 1989-1990 logging utilization study, and on land use change estimates from the new inventary.

3international 1/4-Inch rule. 

Murray, Pat.

1991. Forest statistics for Minnesota's Northern Pine Unit. Resour. Bull. NC-131. St. Paul, MN: U.S. Department of Agriculture, Forest Service, North Central Forest Experiment Station. 41 p.

The fifth inventory of Minnesota's Northern Pine Unit reports 11.1 million acres of land, of which 6.3 million acres are forested. This bulletin presents statistical highlights and contains detalled tables of forest area, as well as timber volume, growth, removals, mortality, and ownership.

KEY WORDS: Forest area, timber volume, growth, removals, mortality. 
Our job at the North Central Forest Experiment Station is discovering and creating new knowledge and technology in the field of natural resources and conveying this information to the people who can use it. As a new generation of forests emerges in our region, managers are confronted with two unique challenges: (1) Dealing with the great diversity in composition, quality, and ownership of the forests, and (2) Reconciling the conflicting demands of the people who use them. Helping the forest manager meet these challenges while protecting the environment is what research at North Central is all about.

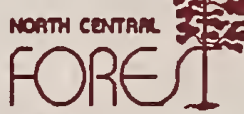

